\title{
Study the Variation of Ozone and Temperature above Iraq for a Long Period from Years 2002-2016
}

\author{
Mohammed A. A ${ }^{1}$, Najat M. R. Al-Ubaidi ${ }^{2}$ \\ Department of Astronomy \& Space, College of Science, Baghdad University, Baghdad, Iraq
}

\begin{abstract}
The most important issues of concern to the world is depletion of the Ozone layer and its related to the climate change, which is always focused on the relationship between them through the temperature change. The aim of this research is to study the variation of Ozone layer and temperature above Iraq (latitude $28-38^{\circ} \mathrm{N}$; longitude $38-49^{\circ} \mathrm{E}$ ) for the years $(2002-2016)$. The data for the monthly average total Ozone column (TCO3) and the temperature (T2m) are taken for two times (00:00 and 12:00 UT). Three Iraqi cities are chosen for this study: Dahuk, Baghdad, Basrah which represents the North, middle and South of Iraq respectively. It is found that in general, the TCO3 in day time greater than night where the difference between night and day about 1 $22 \mathrm{DU}$. Regarding to temperature T2m, the difference between day and night about $9-12^{\circ} \mathrm{C}$. In North the values of TCO3 are greater than middle and South. About the seasonal fluctuations, the values of the TCO3 in spring and winter are greater than summer and autumn, it reaches maximum in 2016 about $410 \mathrm{DU}$ and the minimum in autumn about $260 \mathrm{DU}$. It is found from the results that there is an inverse relation between TCO3 and T2m along period study in Baghdad and Dahuk, but in Basrah the relationship fluctuated between increasing and decreasing.
\end{abstract}

Keywords: Total Column Ozone; Temperature; Iraq

\section{Introduction}

Due to radiation (UV-C $240 \mathrm{~nm}$ and UV-B $320 \mathrm{~nm}$ ) absorption by ozone in the stratosphere, which heats the stratosphere, results in an increase in temperature with increasing altitude. Atmospheric Total Ozone Column (TCO3) is a regulator of radiated energy flow reaching the Earth's surface and reducing temperature extremes between day and night, so the Earth temperature controlled by the thickness of Ozone layer [1,2]. Many instances were observed when variations in TCO3 correlated with the Sun's activity, as a result of the latter; there could also be an increase in the amount of nitrogen oxides, leading to the decrease of ozone [3].

Seasonal variations of ozone concentration brought about by changes of atmosphere circulation are extensive in the higher altitudes. Natural temporary variations could be quite large in comparison with values brought about by expected anthropogenic changes. For instance, at an average global content of Ozone in the Earth's atmosphere equal to 297 Dobson's Units, average monthly values of TCO3 are subject to three-fold seasonal and territorial variations during the year. All these factors up till now did not allow the registration or reliable assessment of the impact of human activities on the Ozone layer, although there is no doubt that this influence is substantial [4]. Ozone depletion in the stratosphere results in enhanced levels of solar UV radiation at the Earth's surface and a positive trend in the UV-dose is also found at the Northern mid latitudes in winter and spring [5]. A different low-ozone phenomenon is the ozone mini-holes, in contrast to the Antarctic ozone-hole, mini-holes are relatively short-lived events, mainly caused by dynamics in the upper troposphere and lower stratosphere that occur regularly throughout the mid-latitudes of both hemispheres [6, 7]. On average, the ozone abundance is reduced by about $10 \%$ in mini-holes. However, on some occasions the ozone amount above the Northern Hemisphere has been reduced by more than $30 \%$, and the ozone value drops below 200 DU [8]. Ozone mini-holes occur most frequent in the Northern Hemisphere at the end of the Atlantic and Pacific storm tracks, during the winter months December-March. The number of mini-hole events has increased since the beginning of the 1980s and may account for up to a third of observed ozone trend in the mid-latitude winter and spring [9].

\section{Previous Studies}

Global studies made to find the behavior of Ozone thickness and its relation to the climate change through many weather parameters. In (1982), Harrison R. M. and Holman C. D. studies the daily variation for the TCO3 in 1978 for British country, they found that the maximum values in spring and minimum in winter [10]. Randel W. J. and Cobb J. B.(1994), they take the data from TOMS satellite for TCO3 and temperature for global area in the world from years (1979-1992). Their results appeared that there is decrease in lower stratospheric temperature especially in the Northern hemisphere for the mid-latitude regions in spring and winter seasons, but in the southern hemisphere especially in the Antarctica the temperature decreases in spring only [11]. Atkinson R. J., (1997), studied the daily variation of TCO3 for Australia from years (1995-1996), he found that the variation of TCO3 from day to day is lower from summer to mid-winter, but this variation became the maximum in spring and this variation increases with latitude [12]. Kalaf al Kalaf (2006), he analyzed the TCO3 above Saudi Arabia country and its daily, monthly average and seasonally variation through year 2004. He found that there is a fluctuation in daily variations, but the maximum variation in summer and spring, minimum variation in winter and autumn [13]. Steinbrecht W, et. al (2003), they are studied the Ozone macro-scale globe and changes in temperature stratosphere, and give a comprehensive review of amendments Ozone total during level pressure $50 \mathrm{hpa}$. Data taken from 1971 to 2001 for Ozone, they found that the change of (10 DU) in the Ozone 


\section{International Journal of Science and Research (IJSR) \\ ISSN (Online): 2319-7064}

Index Copernicus Value (2016): 79.57 | Impact Factor (2015): 6.391

corresponds to change the temperature (1 K) [14]. Hood L. L. and Soukharev B. E, (2005), they study the links between the Ozone and crossovers dynamic in terms of the movement of spiral effort as adopted. Data of the Ozone from (1978-2002) in the mid-latitude from northern hemisphere are taken, they found that their capacities negative super in the months of February and March in the total Ozone, these capacities may be due to changes in the movement of spiral [15]. Zou H, et. al (2005), they studied fluctuations of the total Ozone for period 1979 to 2002 which registered from TOMS for areas between latitude $50^{\circ}$ and $60^{\circ}$ North, they found that during the period selected the Ozone in the north of the Indian Ocean are maximum but it is minimum in the North Atlantic Ocean in winter [16]. Lal. M, (2007), he studies the effected of geomagnetic severe storms on the variations of the Ozone in the equator and pole, based on data TOMS and METERO-3, he found that in the polar region there is an increase in abundance Ozone after the start of the storm, either in the region of tropical there is also an increase in the Ozone but before the storm and beyond [17]. Gao W. and Chang N., (2010), they studies changes between (UV-C) and concentration of total Ozone above north America, based on data satellite and ground, they found in the scale monthly that UV increase at four stations, while the Ozone is decreasing during the period of their studies 1979-2005 [18]. Antón M, et, al (2011), have analyzed total column Ozone taken from TOMS above Portugal for period 1979 - 2005. Their analysis spatial studies showed that it depends on the months and latitude. As well as they found that the rate of total Ozone in northern part of Portugal greater than of the South [19]. The first study in Iraq done by Al-Salihi A. M, (2008), he studied the effect of some weather conditions on ultraviolet radiation, he found that aerosol and gaseous cover a clear effect on the amount of ultraviolet radiation [20]. AlSalihi A. M, (2011), analyzed the TOC data for the period from 1978 to 1993 over the city of Baghdad and then studied its relationship with solar activity. The slope was extracted over time and the ozone slope during this period was found to be -0.33

DU / yr. From the spectral analysis of the daily values of the data above, it was found that the periods of oscillation prevailing ranged from 2.8 to 5.4 days and obtained that the relationship between ozone and solar activity was weak with a correlation coefficient of 0.22 [21]. Sadi. A. R and Zahra. A. K (2013), they conducted a study on total ozone column changes over selected regions in the Northern Hemisphere. The results of data analysis of daily ozone values showed that there was an increase in these values for most of the selected sites that included the study [22]. Al-Salhi and Zahra Mousa (2014), they conducted a study on the analysis of temporal and spatial patterns of ozone over Iraq and found that the highest values exist in the northern region during winter months while in the spring and early summer will be the highest values in the northwestern regions of the Iraqi country [23]. Sarah. A. M (2015), analysis and study the monthly values quarterly and annual TCO3 and UV rays and the relation between them to the four Iraqi cities for years (1980-013). It is found that the TCO3 for all cities fluctuated for the monthly average but, for the seasonally variation for north it is inversely related middle it is inversely in all season except for autumn it is increase in south of Iraq it is inversely in winter and spring increase in autumn and summer. For the annual variation it is inversely propagate for all cities [24]. The purpose of our research is to study the monthly average of the Ozone layer thickness and the temperature variation over Iraqi region. Also, to find the nature of the relationship between the variation of total column Ozone and temperature variation for three Iraqi cities (Dahuk, Baghdad, and Basrah), from which the climate change studied over North, middle and south of Iraqi regions.

\section{Climate in Iraq}

The climate in Iraq is mainly of the continental, subtropical semi-arid type, with the north and north-eastern mountainous regions having a Mediterranean climate. Rainfall is very seasonal and occurs in the winter from December to February, except in the north and northeast of the country, where the rainy season is from November to April. Winters are cold and cool, with a day temperature of approximately $16^{\circ} \mathrm{C}$ dropping at night to $2^{\circ} \mathrm{C}$ with a possibility of frost. Summers are hot and dry, with a shade temperature of over $\left(43^{\circ} \mathrm{C}\right)$ during July and August, yet dropping at night to $26^{\circ} \mathrm{C}[25,26]$. There are many factors that effects on the climate change in Iraqi region such as solar energy distribution see figure (1) [27], location of Iraq in the northern hemisphere throughout cancer, so the angle of the fall of the Sun (solar zenith angle) and the length of the day, the length of the Sun rises has gained from this site its temperature similar to the tropical [25], Proximity to the water bodies, Iraq located a far distance from the water areas (Arabian Gulf and the Arabian Sea), and The height of the mountains and the form of extension [28, 29, 30].

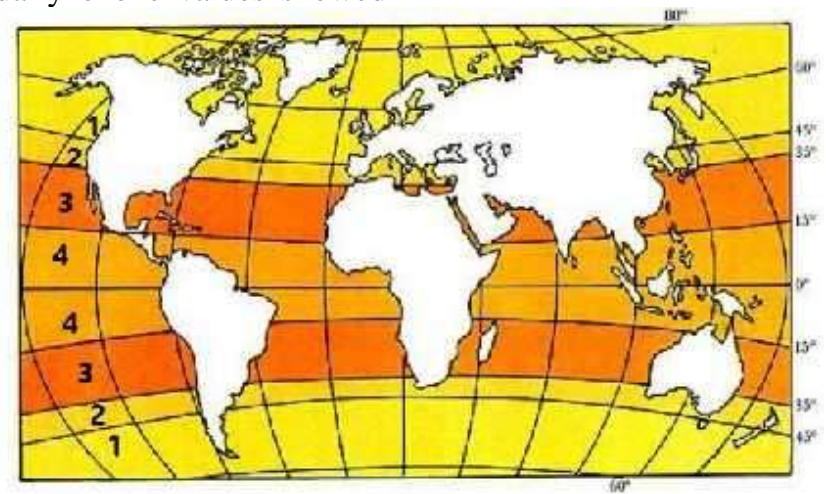

Figure 1: Worldwide distribution of solar radiation.

(1) Least favorable belt (2) Less (3) Most (4) and Moderately [27].

Volume 6 Issue 12, December 2017 www.ijsr.net

Licensed Under Creative Commons Attribution CC BY 


\section{International Journal of Science and Research (IJSR) \\ ISSN (Online): 2319-7064 \\ Index Copernicus Value (2016): 79.57 | Impact Factor (2015): 6.391}

The astronomical location of Iraq's and its distance from the sea make its climate described the continental and falls within the tropical region in the southern hemisphere [31]. The climate of Iraq divided into three regions according to the regional planning or contour lines for the temperature distribution as: mountain region, Climate of the steppe, Desert climate [32, 33].

\section{Data Selection}

The data for the total Ozone column and the temperature (2m) above Iraqi region (latitude $28-38^{\circ} \mathrm{N}$; longitude 38 $49^{\circ}$ E) were chosen from the site (http://apps.ecmwf.int) from (ERA) for the period (2002 - 2016). The data which is selected were divided into daily, seasonally for two Universal times (00:00 UT and 12:00 UT). Four seasons are selected, represented by January (winter), April (spring), July (summer) and October (autumn). For this study three cities from Iraqi regions are chosen: Dahuk, Baghdad, Basrah which represents the North, middle and South of Iraq respectively.

\section{Data Analysis and Results}

Data which is selected divided into four seasons and two times night and day. Figures (2, 3, 4 and 5) reveal the contour maps of the monthly average for TCO3 and T2m for seasons through the months $(1,4,7$, and 10) for hour (00:00UT) and hour (12:00UT) respectively. And due to the long period and huge of data, only five years 2002, 2006, 2010, 2014 and 2016 are taken for representation.

\section{Daily Variations}

To present the Ozone variation with climate change through the temperature, Iraqi region divided into three categories Baghdad (latitude, $33^{\circ} \mathrm{N}$; longitude, $44^{\circ} \mathrm{E}$ ), Basrah (latitude, $30^{\circ} \mathrm{N}$; longitude, $47^{\circ} \mathrm{E}$ ), and Dahuk (latitude, $37^{\circ} \mathrm{N}$; longitude, $43^{\circ} \mathrm{E}$ ) which are chosen on the basis of geographical location to represent the north, middle and south. Figures (6-10 a, b, c, d) show the amount of change in the thickness of the Ozone layer (TCO3) and the temperature (T2m) throughout the four seasons (winter for January and spring for April and summer for July and autumn for October), during two times (00:00, 12:00 in UT) respectively, for the five years chosen and for the three cities (Baghdad, Dahuk and Basra) respectively. The fluctuations of the TCO3 and T2m appeared very clearly for this long period. From these figures, the line curve fitting (displayed on the graph) gives the slope which is represent the daily variation of Ozone and the temperature through the month of the years chosen.

\section{Seasonally Variations}

Figure (11) gives the seasonal fluctuations through the four month taken $(1,4,7$, and 10) from which the nature of the change of the TCO3 and its relationship toT $2 \mathrm{~m}$ can be seen for three cities (Baghdad, Basrah and Dahuk) in Iraqi region, data for each season separately are taken along the period for years (2002-2016). Also, two universal times are taken, (00:00) for daytime and (12:00) for nighttime. The y-axis on the Figure (11) reveals the TCO3 (DU) and $\mathrm{T} 2 \mathrm{~m}\left({ }^{\circ} \mathrm{C}\right)$ on the $\mathrm{x}$-axis, the trend line equation gives the amount change of $\mathrm{TCO} 3$ relative to $\mathrm{T} 2 \mathrm{~m},(\Delta \mathrm{TCO} 3 /$ $\Delta \mathrm{T} 2 \mathrm{~m})$.

\section{Conclusion}

From the results displayed for the variation of total column Ozone and temperature above Iraq, it is concluded that the TCO3 fluctuated between the North, middle and South of Iraq. There are a daily, seasonally and annually variations of Ozone thickness above Iraqi region specially the three cities Baghdad, Basrah, and Dahuk with temperature variations. It appears in general that in spring and winter greater than summer and autumn maximum in 2016 in spring reach 410 DU and the minimum in Autumn reach 260 DU, but there is anomaly for Dahuk, in the day time it is the same relation as in night time it is directly related except in autumn there is anomaly it is inversely related. In North of Iraq is greater than the values in the middle and South, and in the day time is greater than in night time and the difference between day and night is approximately it reaches from 1-22 DU depending on the season and year. But that $\mathrm{T} 2 \mathrm{~m}$ it is in the day greater than the night, the difference between day and night reaches 9-12 $\mathrm{C}^{\mathrm{o}}$.

From the daily variation of the $\mathrm{TCO} 3$ and $\mathrm{T} 2 \mathrm{~m}$ it is different from the month to another and from city to anther and there is inversely relation between them. There is anomaly, for Basrah in winter, the temperature increases with increasing the Ozone thickness which is maybe due to greenhouse effect (not within our study) there is other factors which is affects the weather fluctuation or the climate change, such as the Oil wells and the population density in South of Iraq it is more than Middle and North, as well as the water vapor or the relative humidity is very high in south because of its nearest to the Arabian Gulf all these factors which are affect the Ozone thickness fluctuation. 
International Journal of Science and Research (IJSR)

ISSN (Online): 2319-7064

Index Copernicus Value (2016): 79.57 | Impact Factor (2015): 6.391

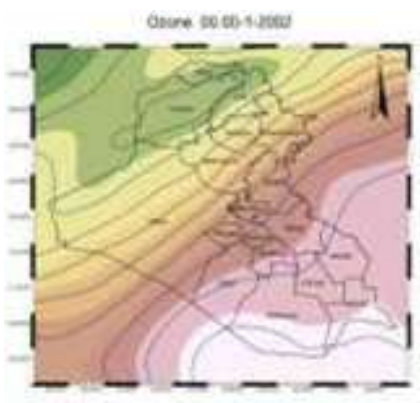

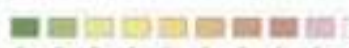

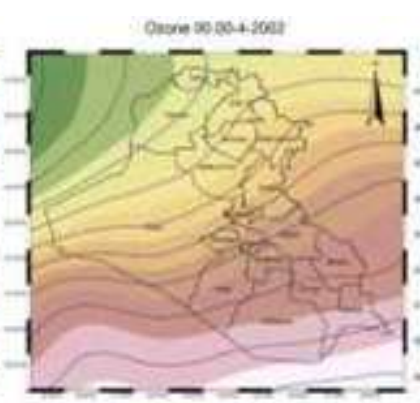

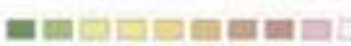

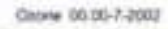

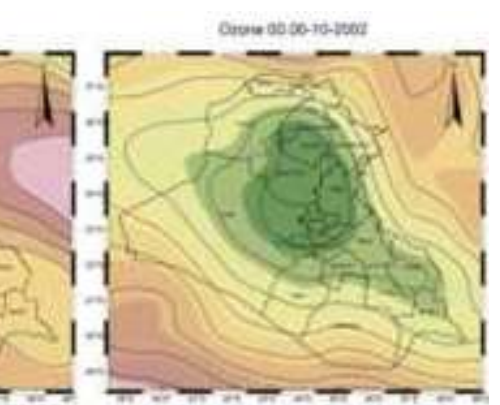

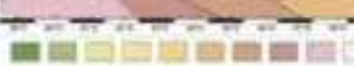

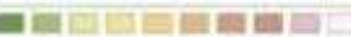
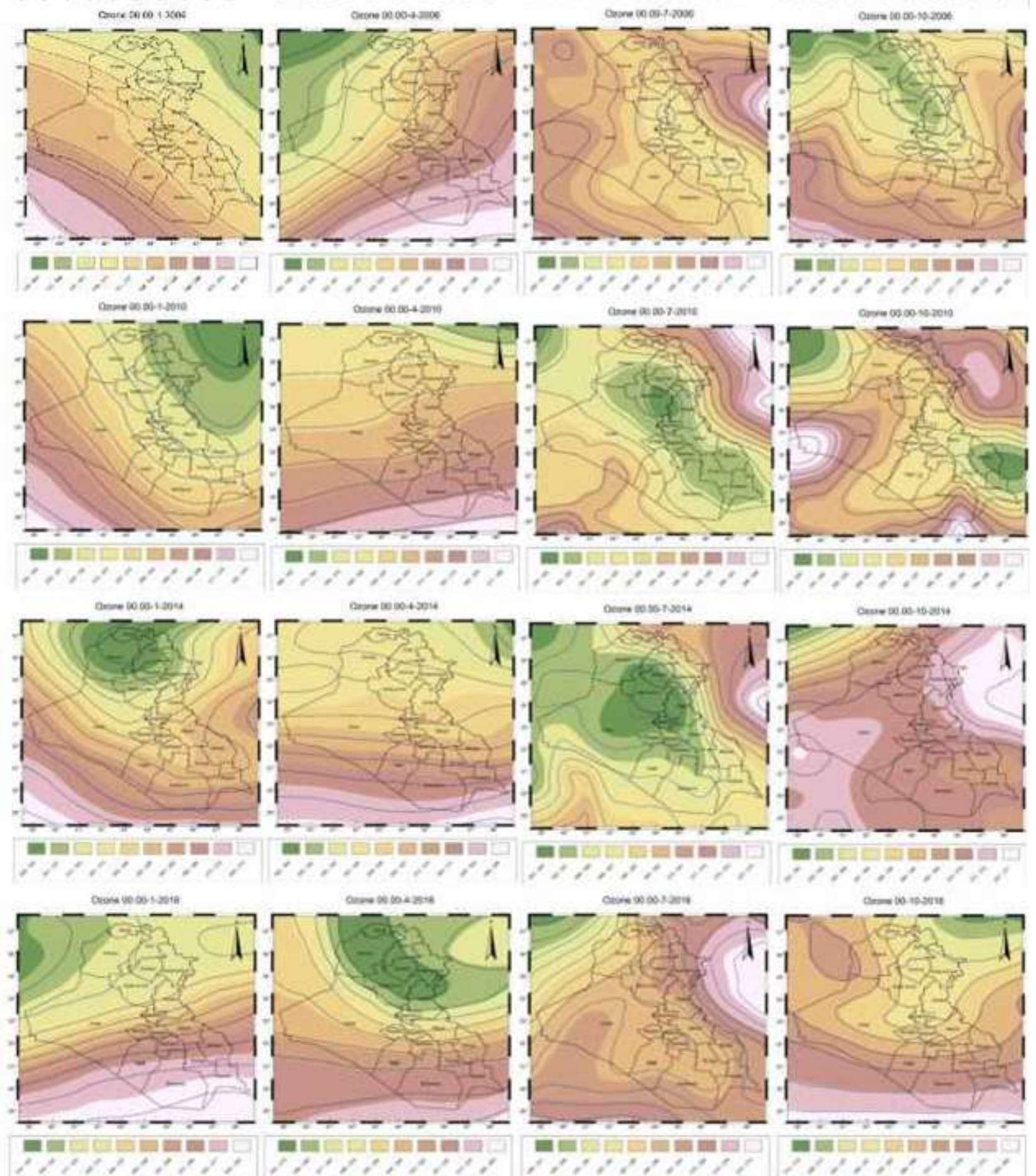

Figure 2: represents the monthly average TCO3 above Iraq for hour 00:00.

Volume 6 Issue 12, December 2017 www.ijsr.net

Licensed Under Creative Commons Attribution CC BY 


\section{International Journal of Science and Research (IJSR) \\ ISSN (Online): 2319-7064}

Index Copernicus Value (2016): 79.57 | Impact Factor (2015): 6.391
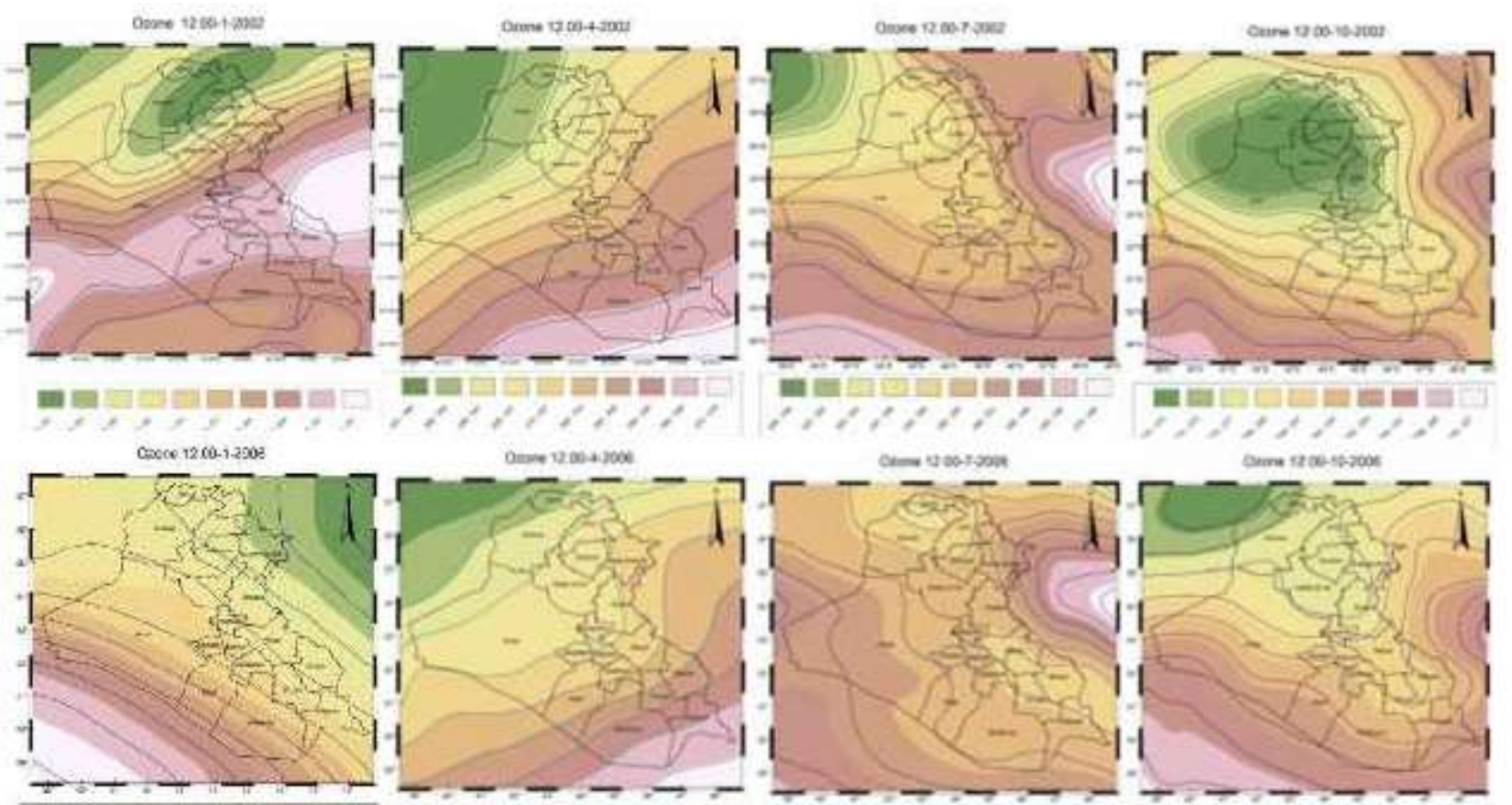

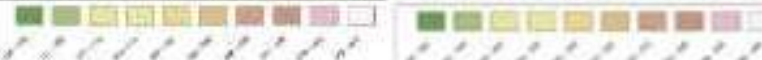

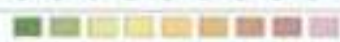

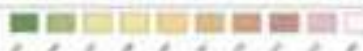
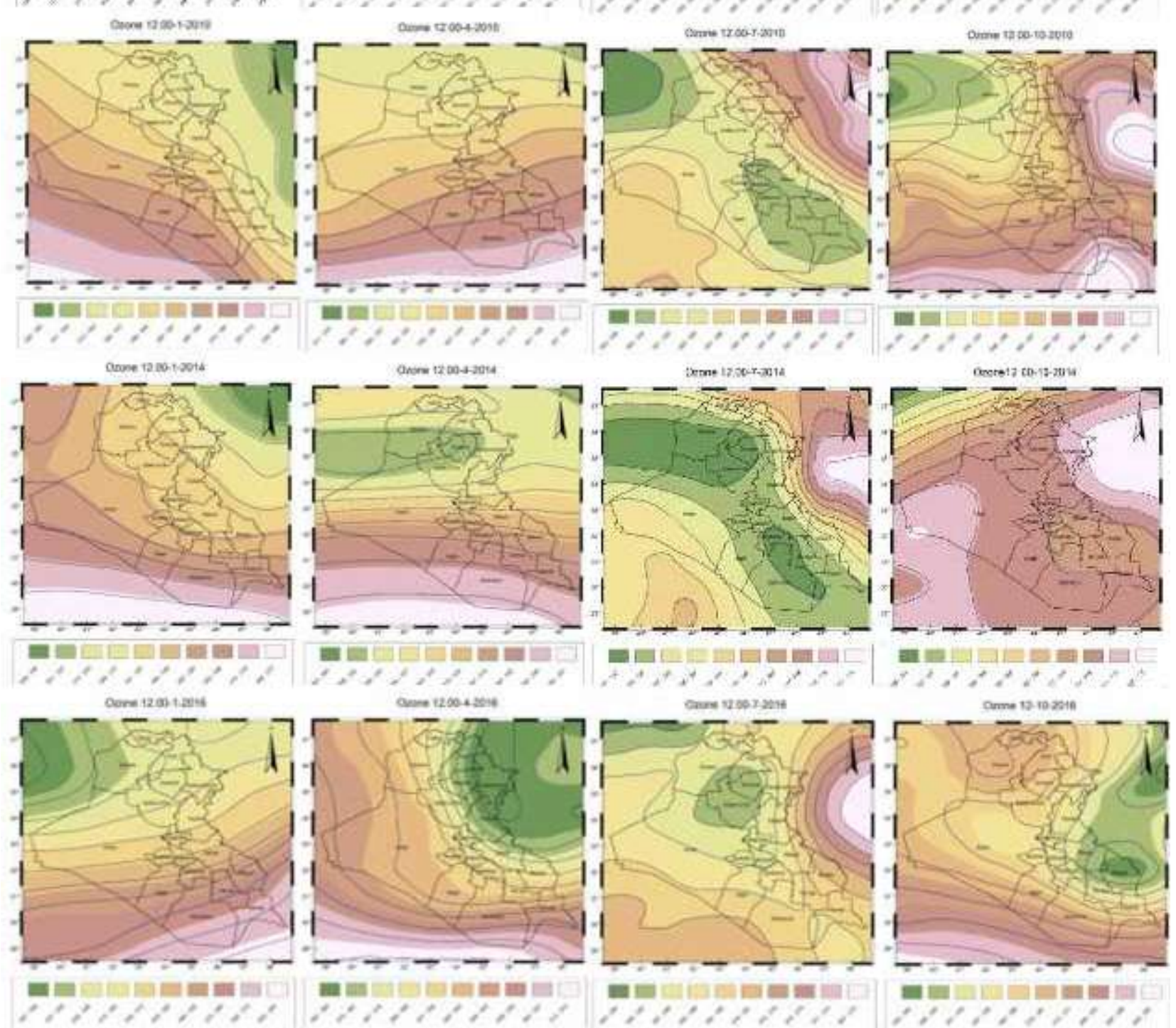

Figure 3: represents the monthly average TCO3 above Iraq for hour 12:00

Volume 6 Issue 12, December 2017

www.ijsr.net

Licensed Under Creative Commons Attribution CC BY 
International Journal of Science and Research (IJSR)

ISSN (Online): 2319-7064

Index Copernicus Value (2016): 79.57 | Impact Factor (2015): 6.391
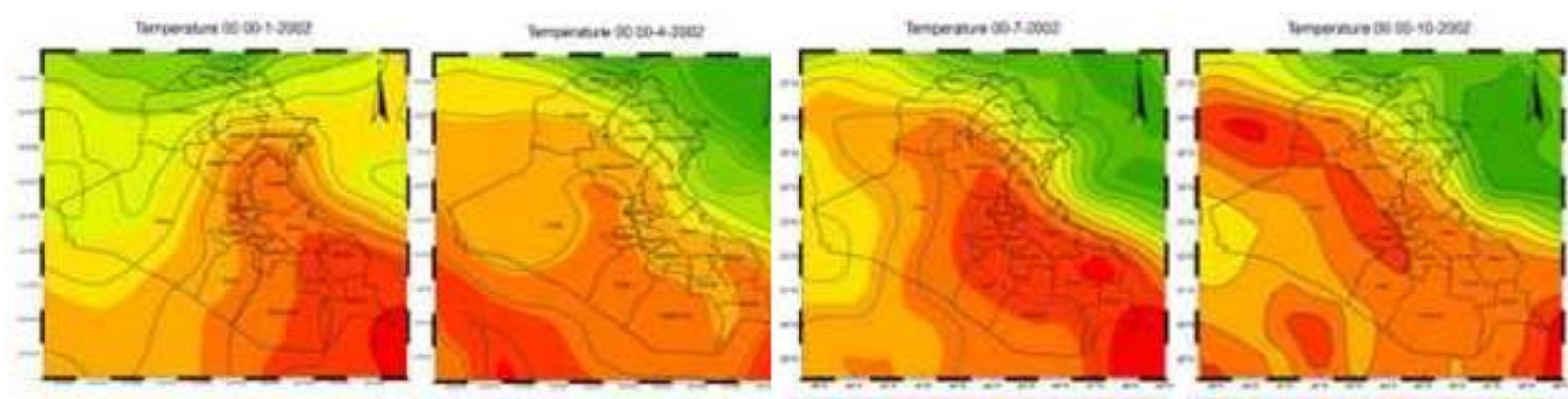

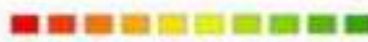

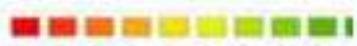

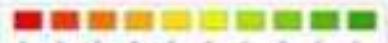

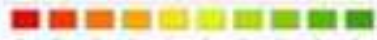
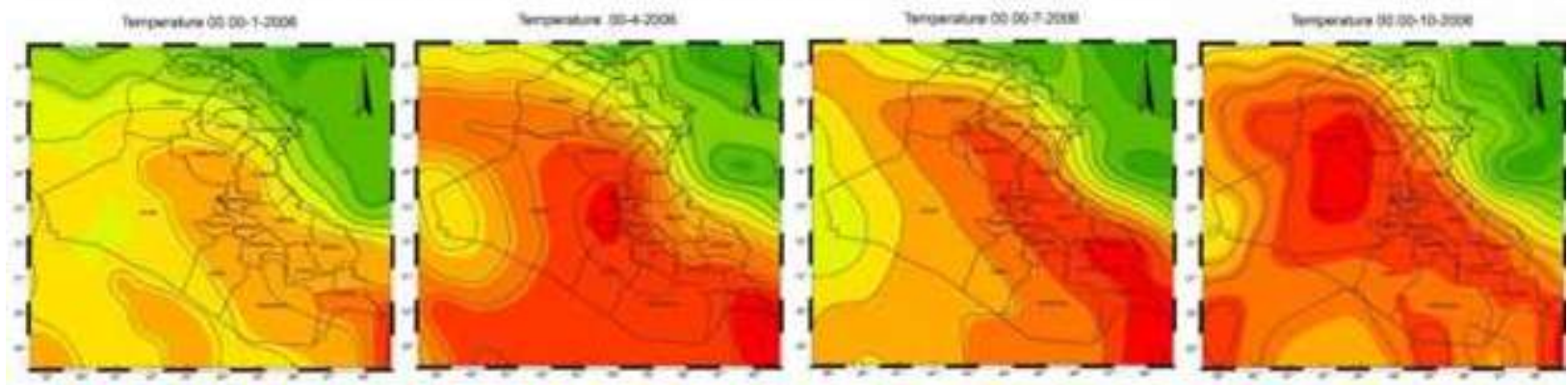

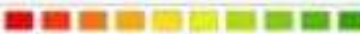

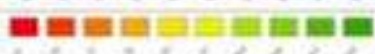

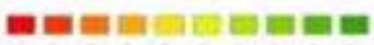

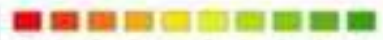

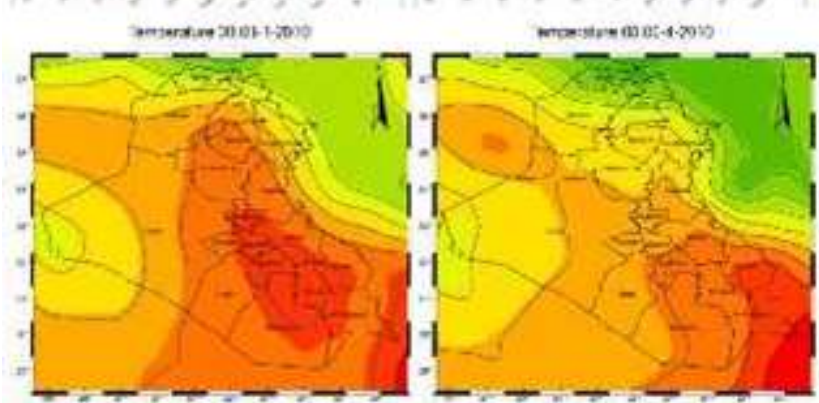

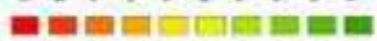

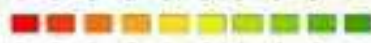
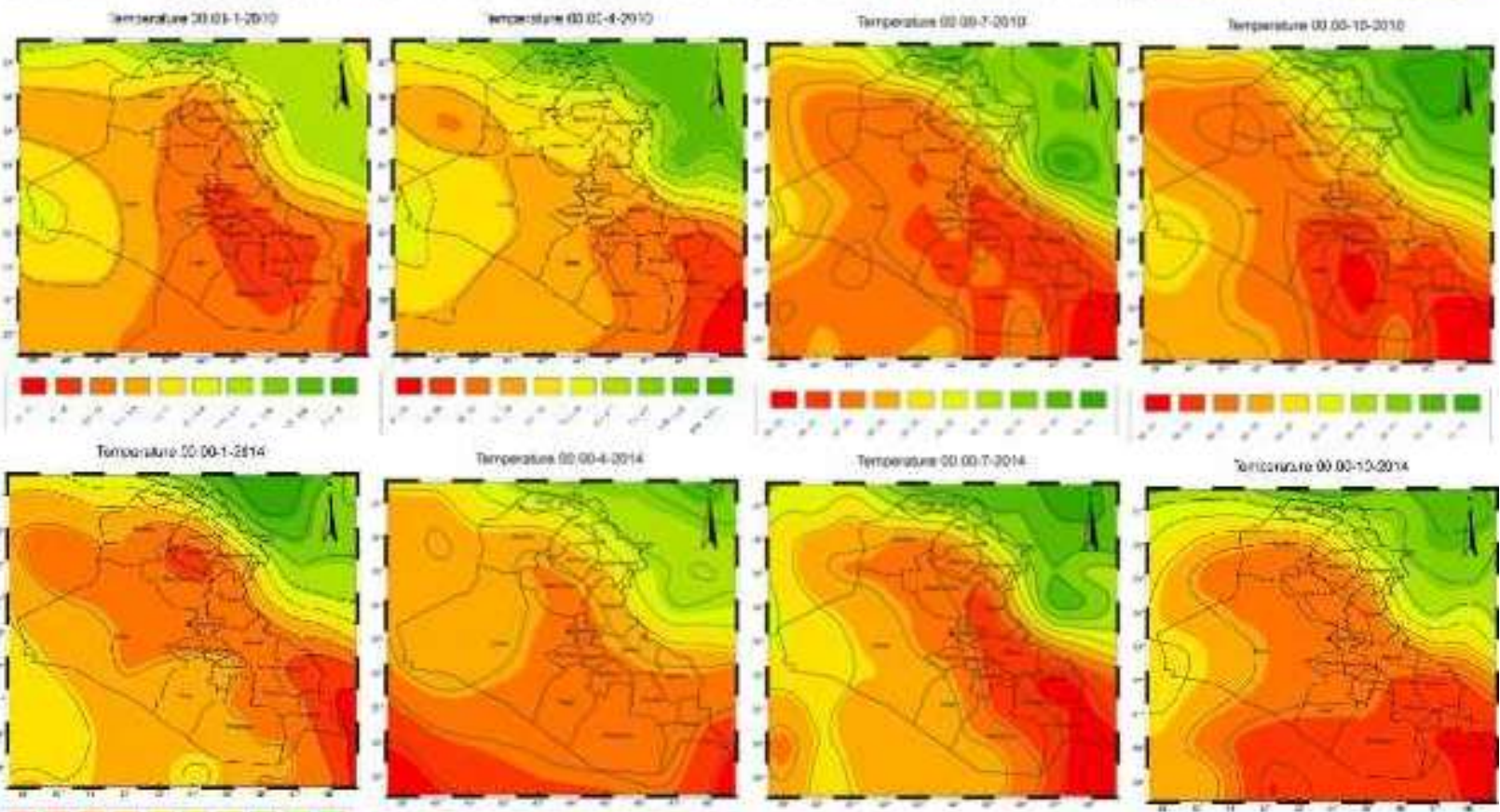

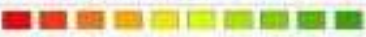

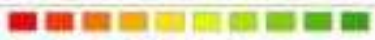

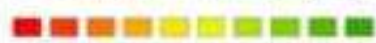

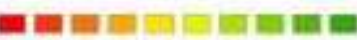
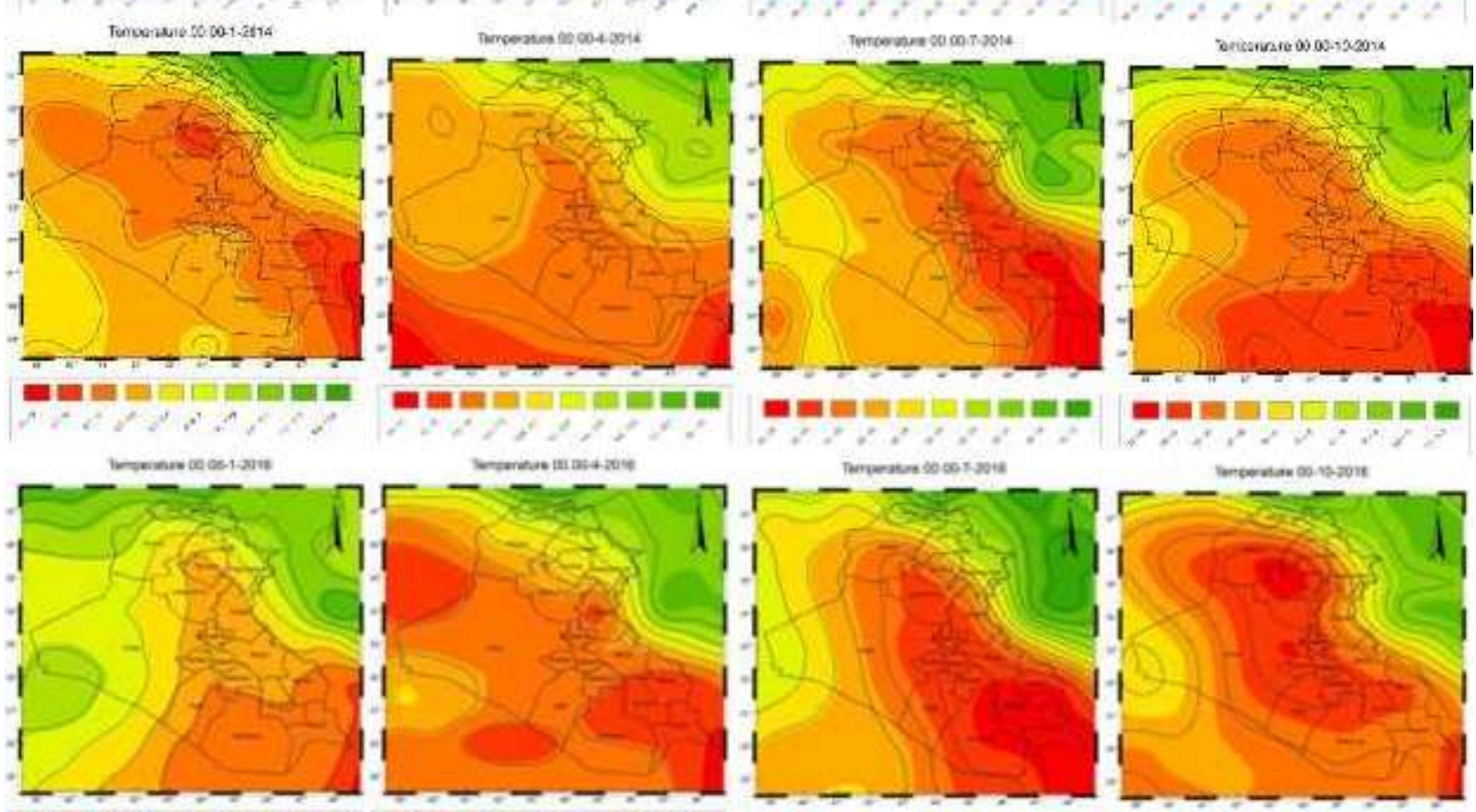

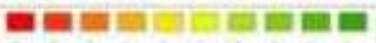
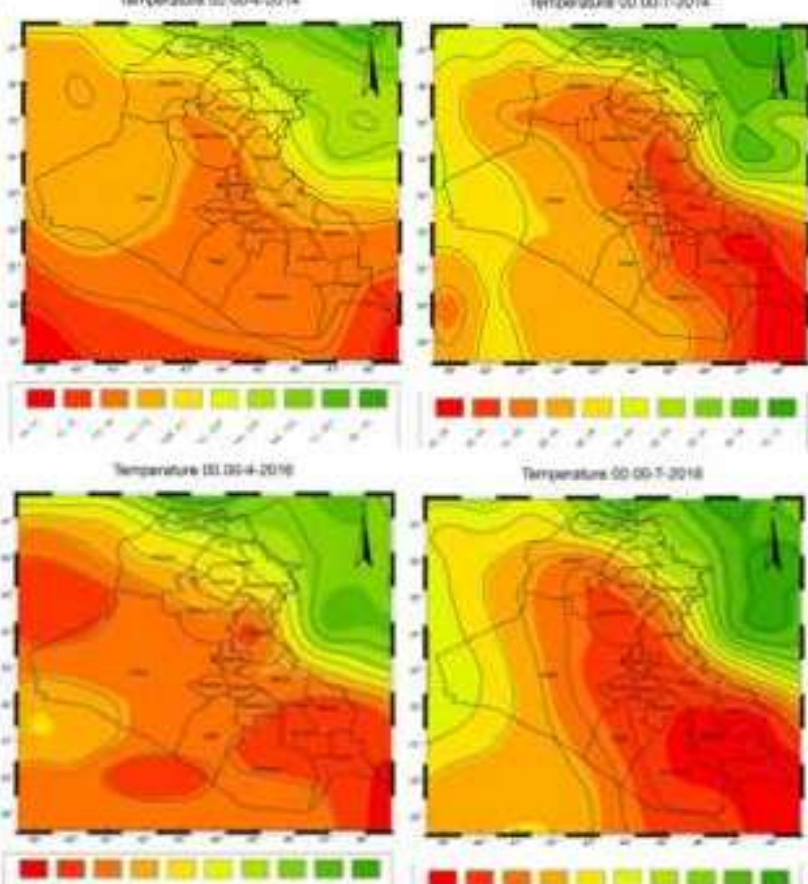

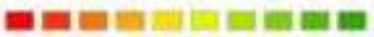

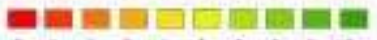
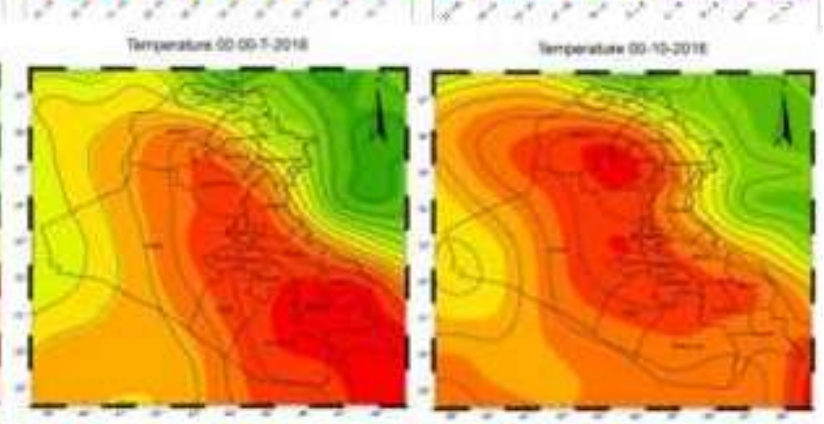

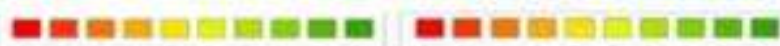

Figure 4: represents the monthly average T2m above Iraq for hour 00:00.

Volume 6 Issue 12, December 2017 www.ijsr.net

Licensed Under Creative Commons Attribution CC BY 
International Journal of Science and Research (IJSR)

ISSN (Online): 2319-7064

Index Copernicus Value (2016): 79.57 | Impact Factor (2015): 6.391
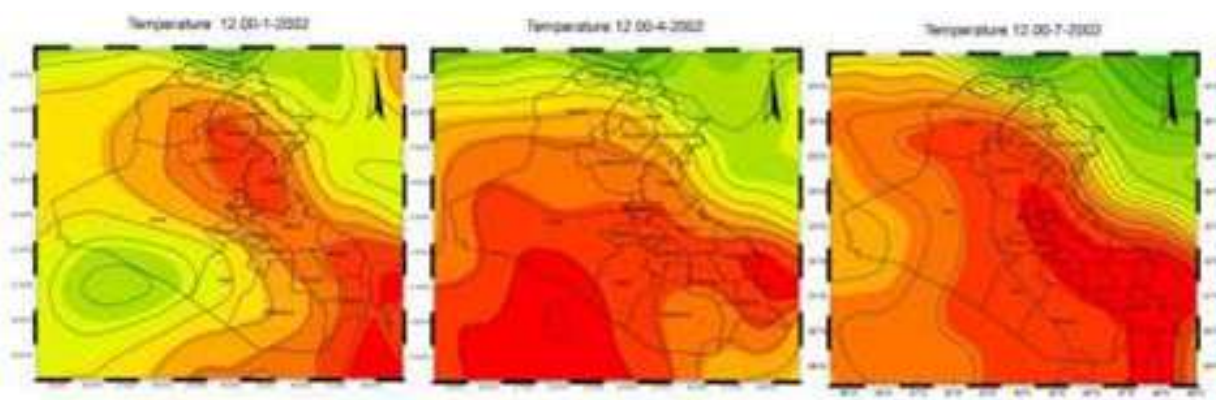

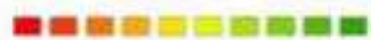

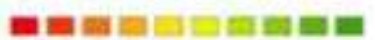

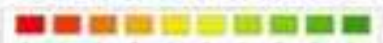
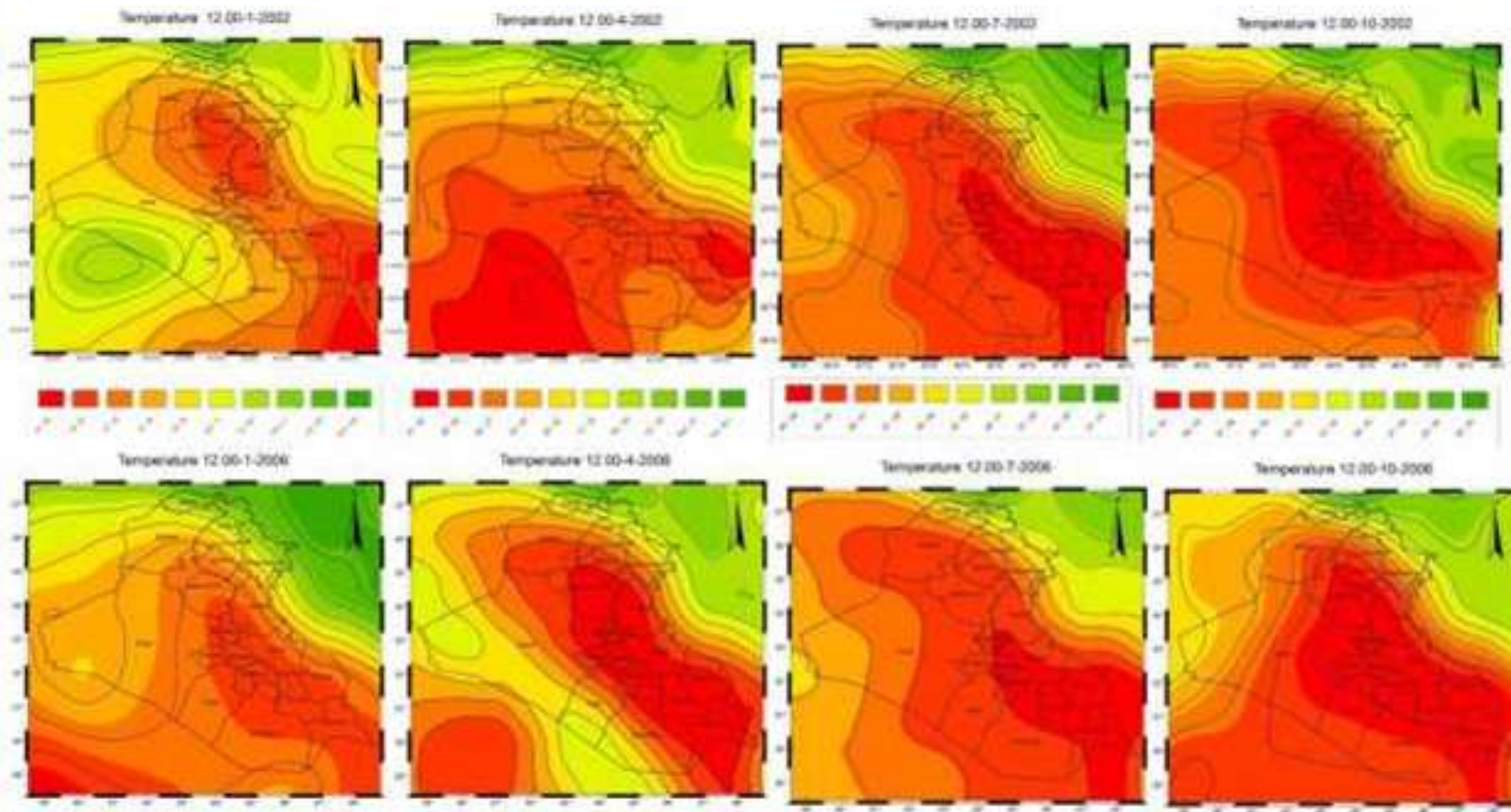

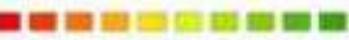

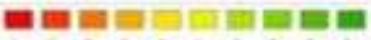

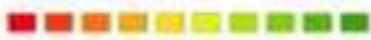

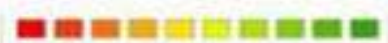
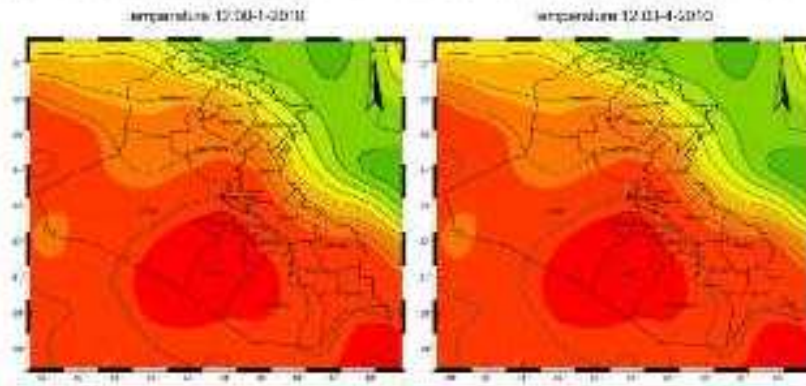

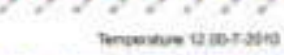

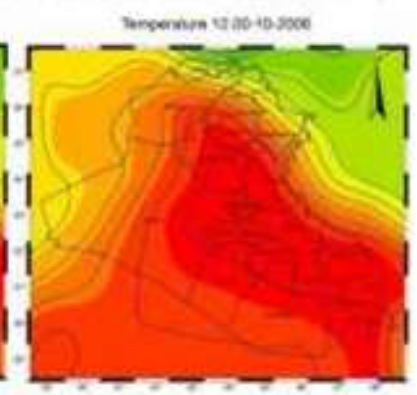

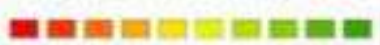

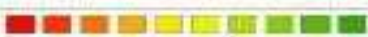
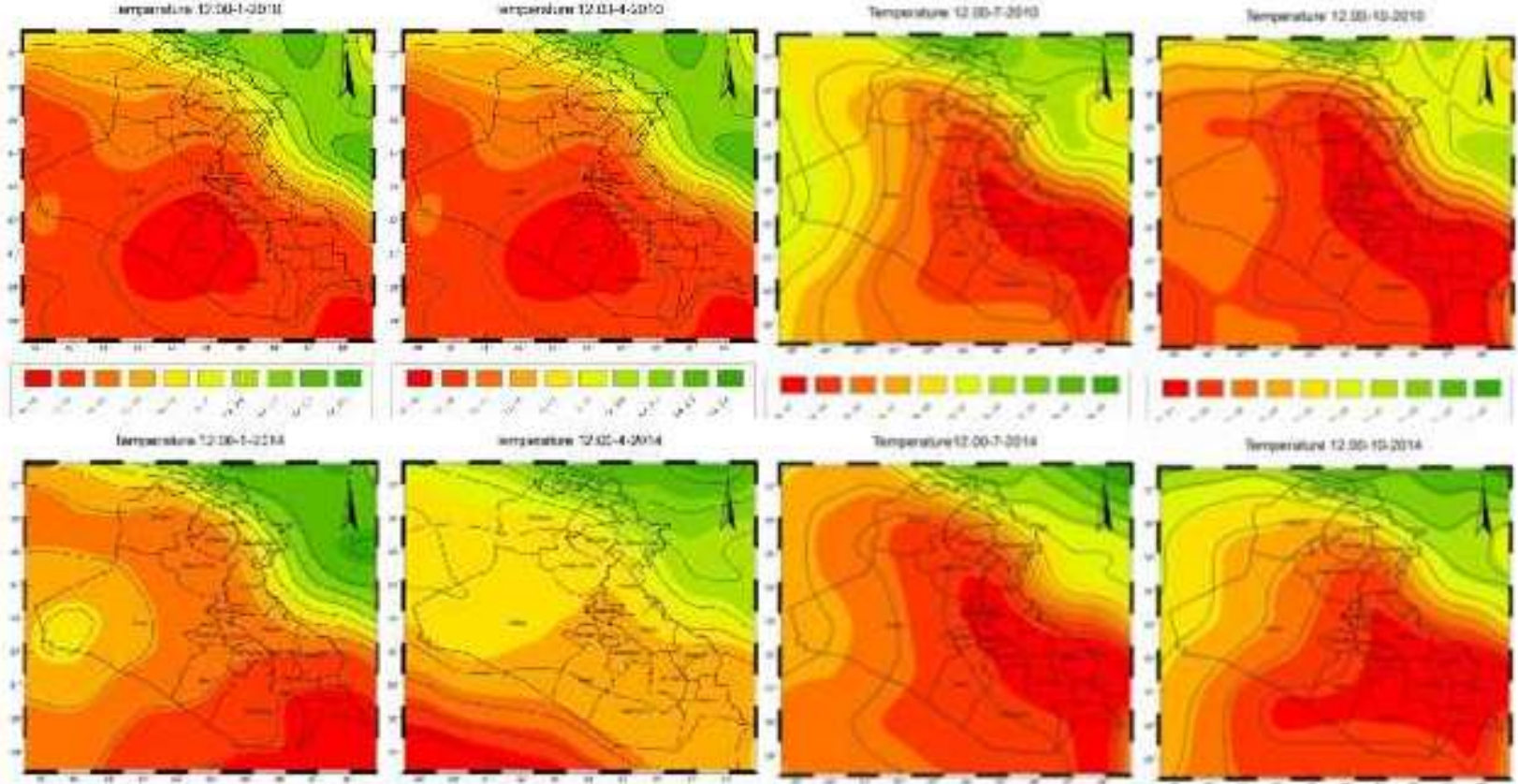

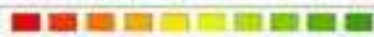

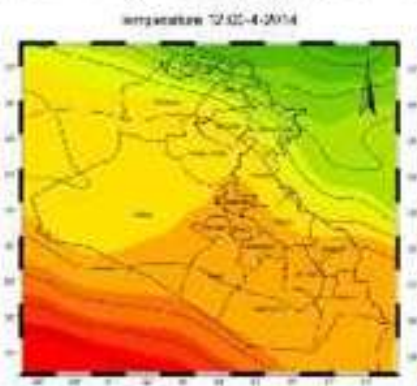

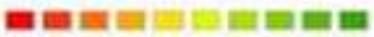

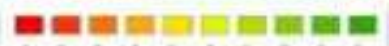

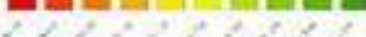

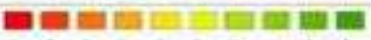
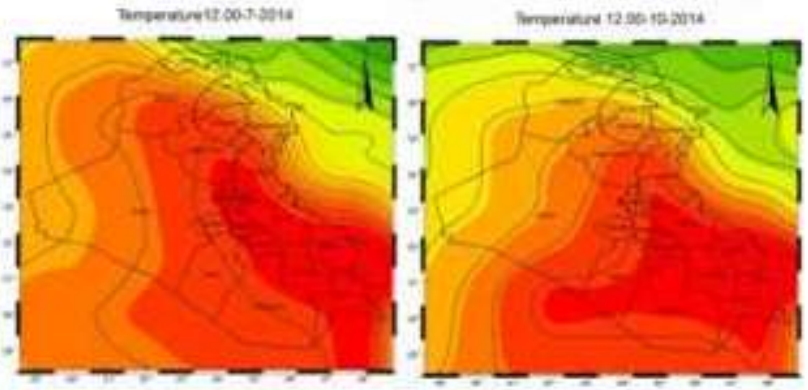

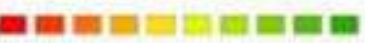

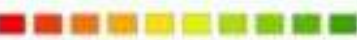
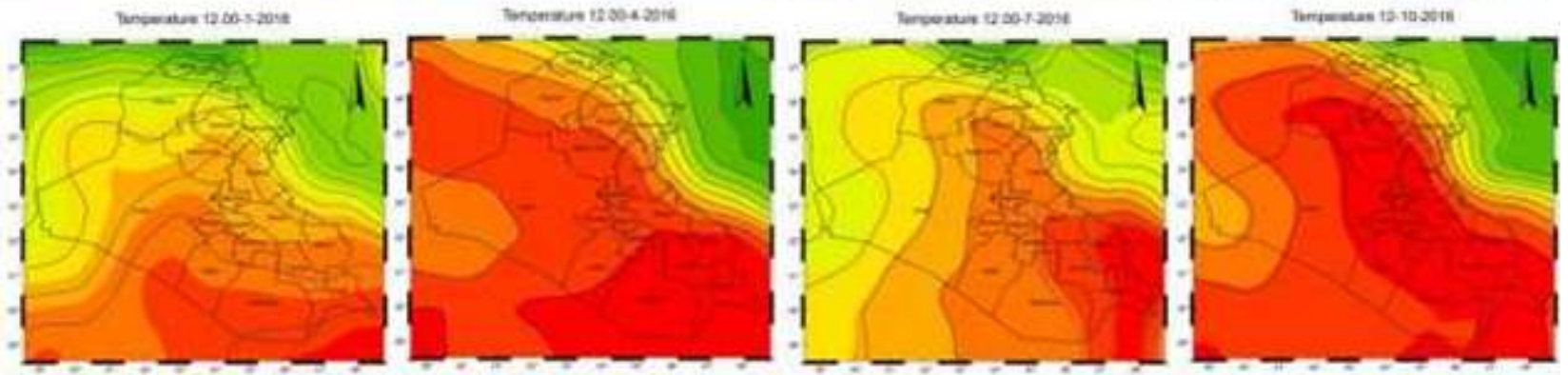

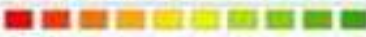

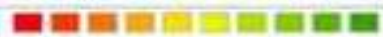

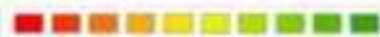

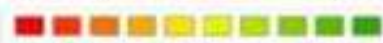

Figure 5: represents the monthly average T2m above Iraq for hour 12:00.

Volume 6 Issue 12, December 2017

www.ijsr.net

Licensed Under Creative Commons Attribution CC BY 
International Journal of Science and Research (IJSR)

ISSN (Online): 2319-7064

Index Copernicus Value (2016): 79.57 | Impact Factor (2015): 6.391

2002 hour 00:00

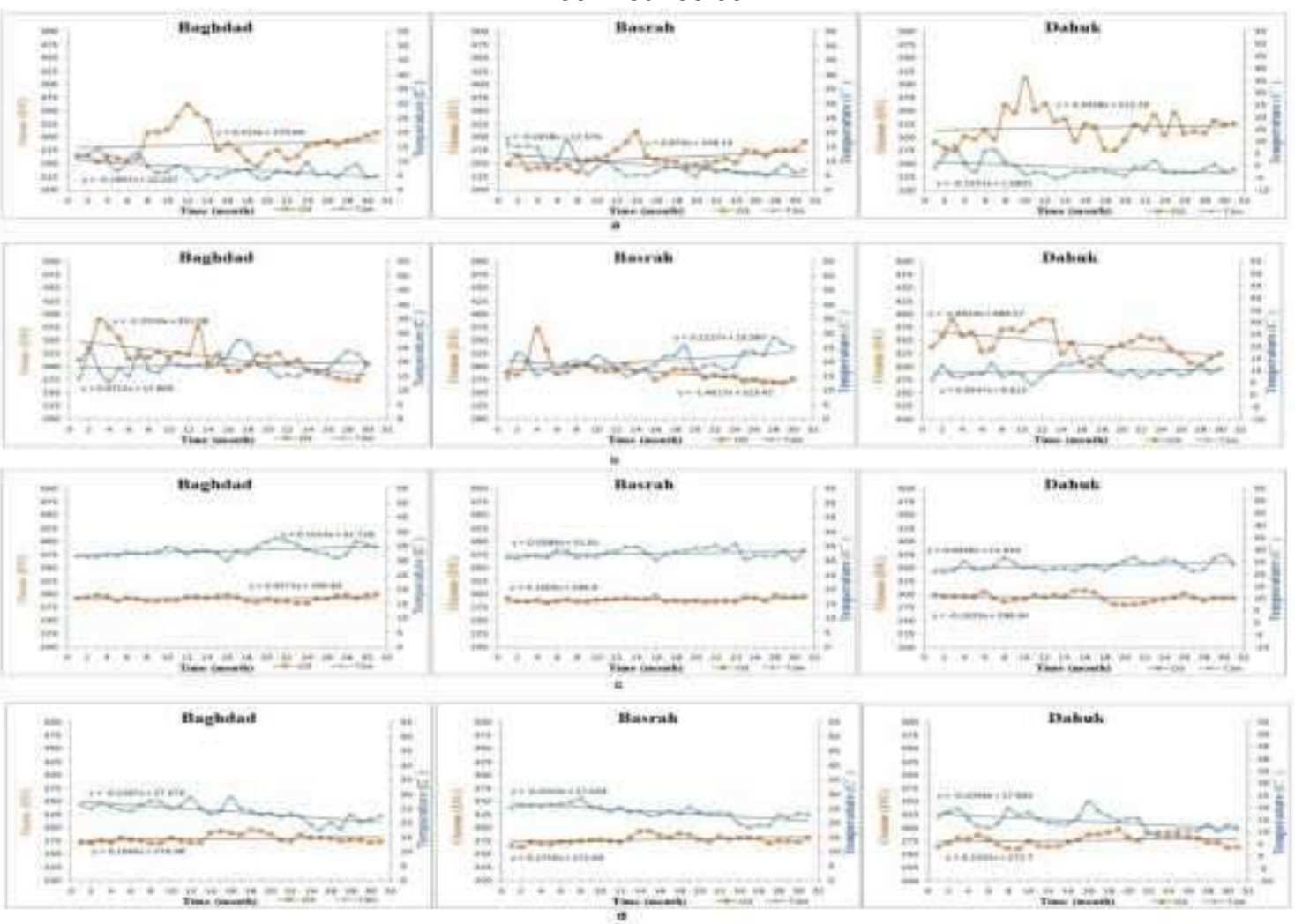

2002 hour 12:00

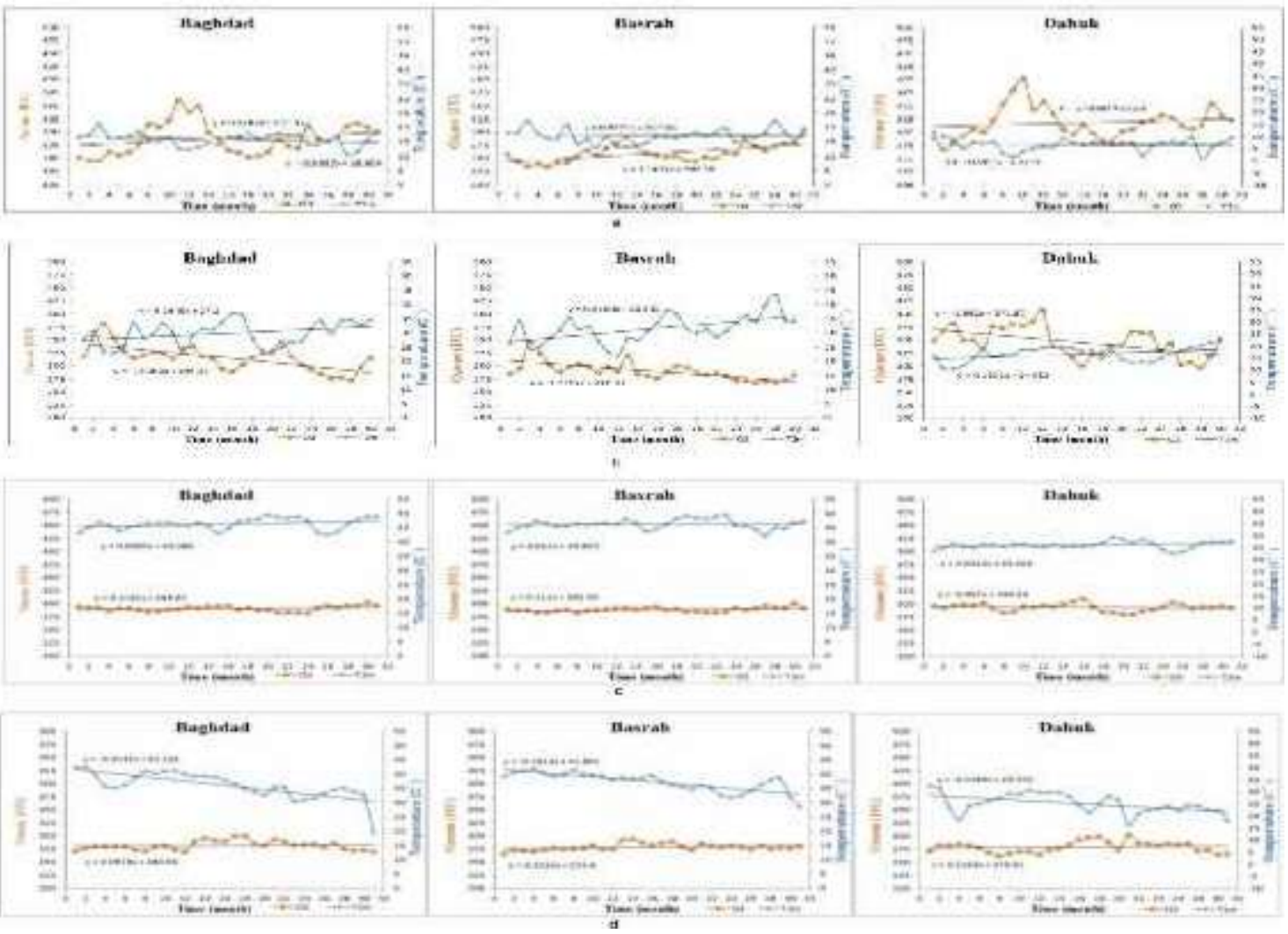

Figure 6: represents the daily average TCO3 and T2m above Iraq

a) January, b) April, c) July, d) October for hour 00 and 12 (year 2002) 
International Journal of Science and Research (IJSR)

ISSN (Online): 2319-7064

Index Copernicus Value (2016): 79.57 | Impact Factor (2015): 6.391

2006 hour 00:00
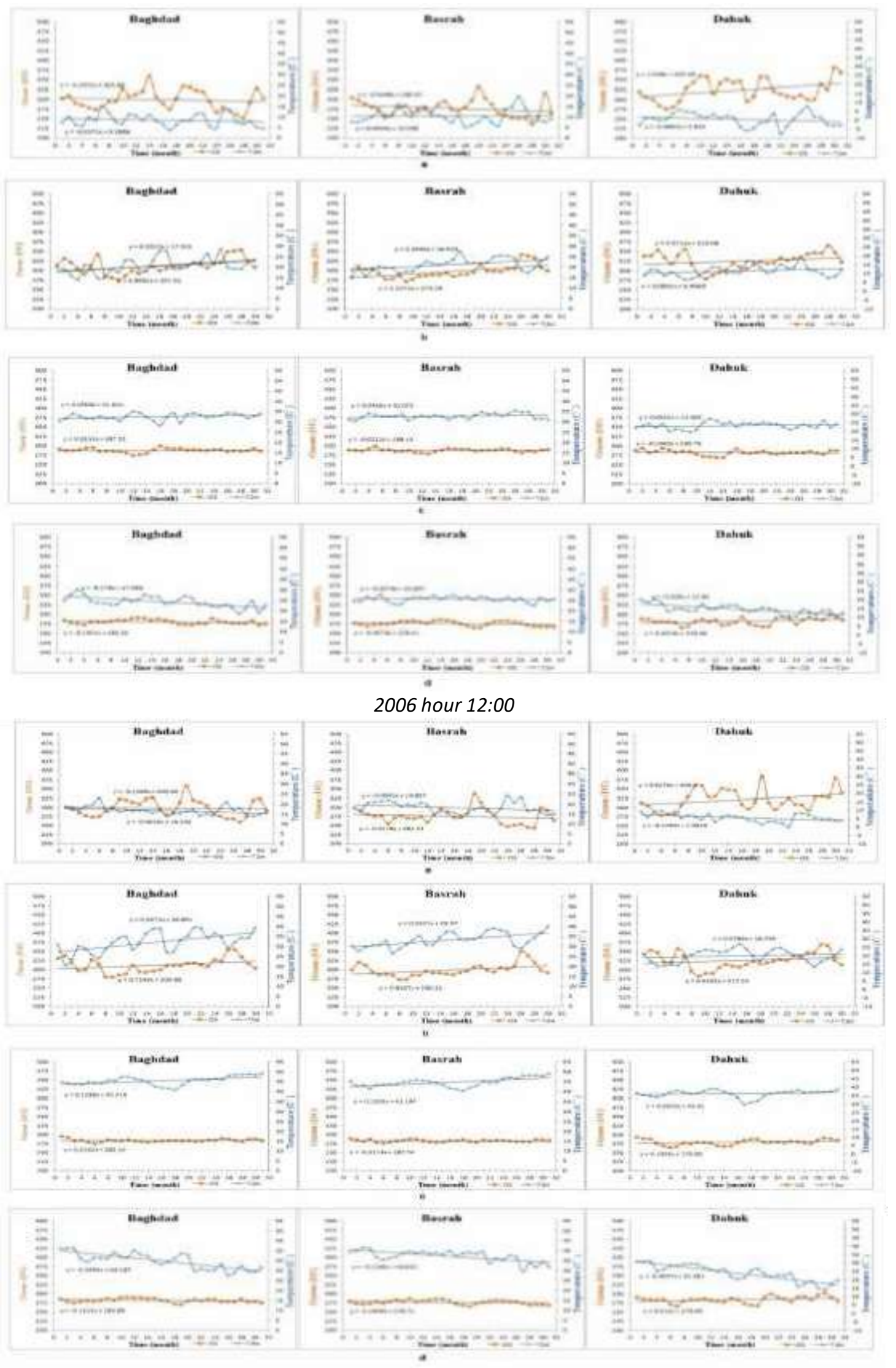

Figure 7: represents the daily average $\mathrm{TCO} 3$ and $\mathrm{T} 2 \mathrm{~m}$ above Iraq

a) January, b) April, c) July, d) October for hour 00 and 12 (year 2006) 
International Journal of Science and Research (IJSR)

ISSN (Online): 2319-7064

Index Copernicus Value (2016): 79.57 | Impact Factor (2015): 6.391

2010 hour 00:00

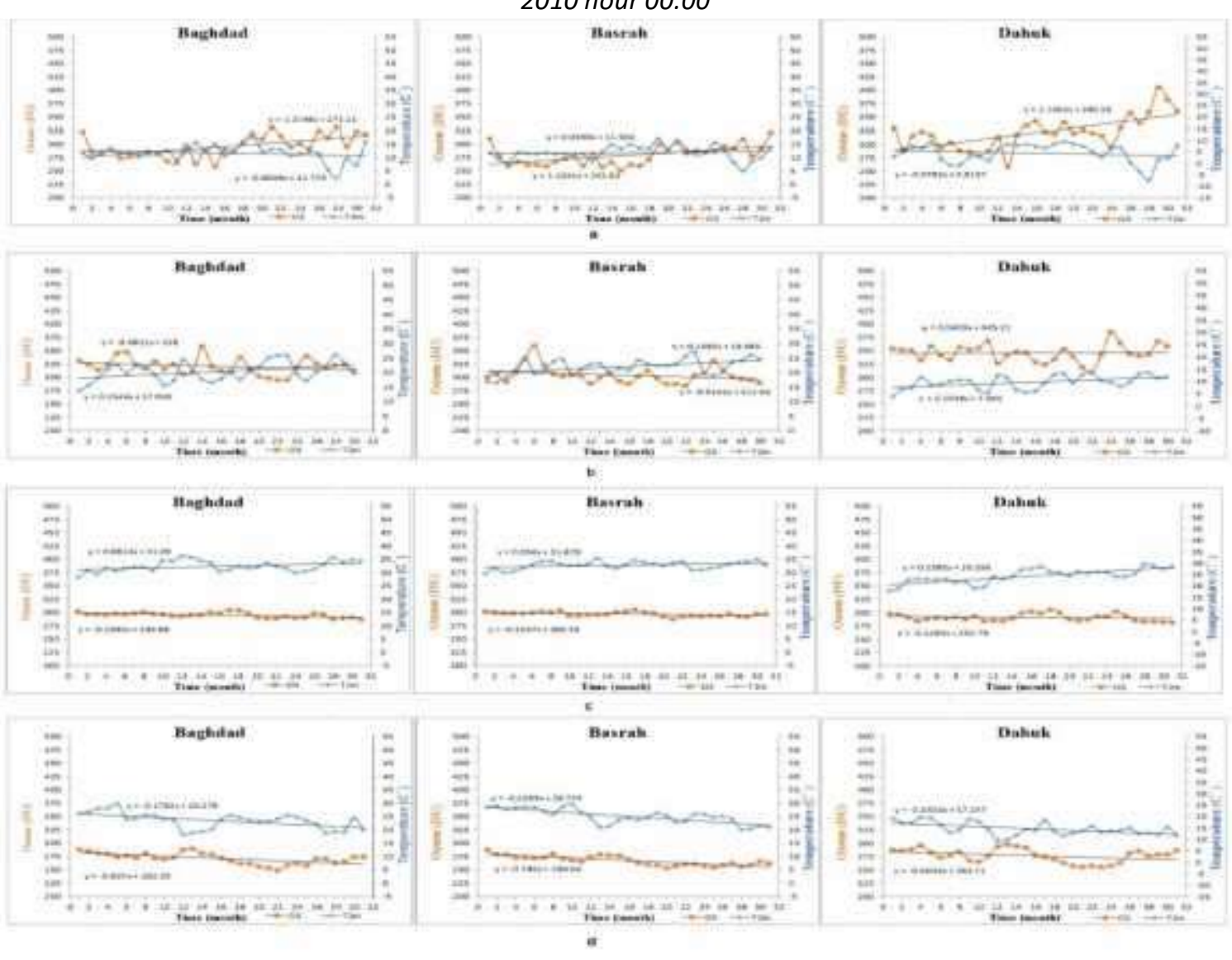

2010 hour 12:00

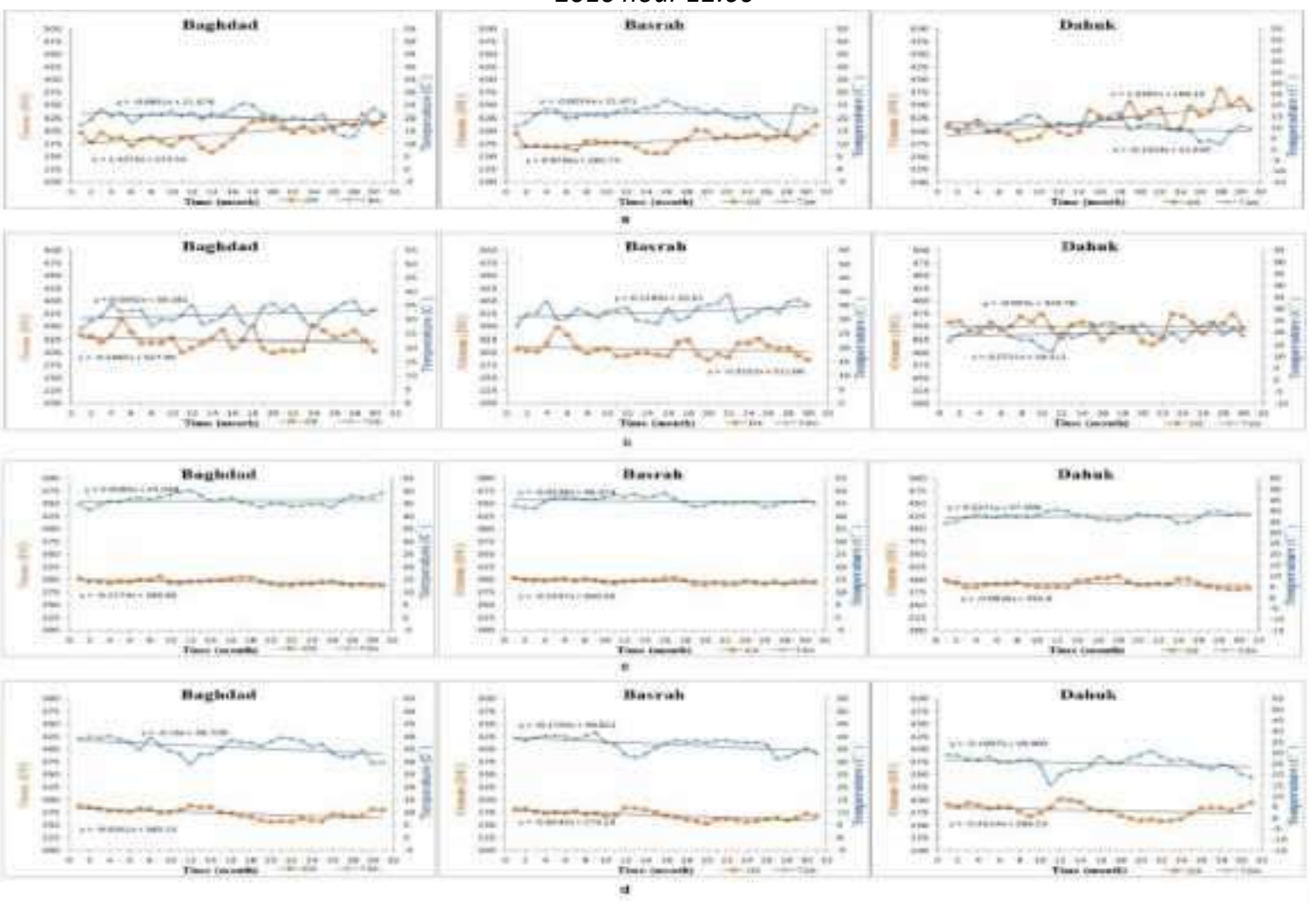

Figure 8: represents the daily average TCO3 and T2m above Iraq a) January, b) April, c) July, d) October for hour 00 and 12 (year 2010) 
International Journal of Science and Research (IJSR)

ISSN (Online): 2319-7064

Index Copernicus Value (2016): 79.57 | Impact Factor (2015): 6.391

2014 hour 00:00

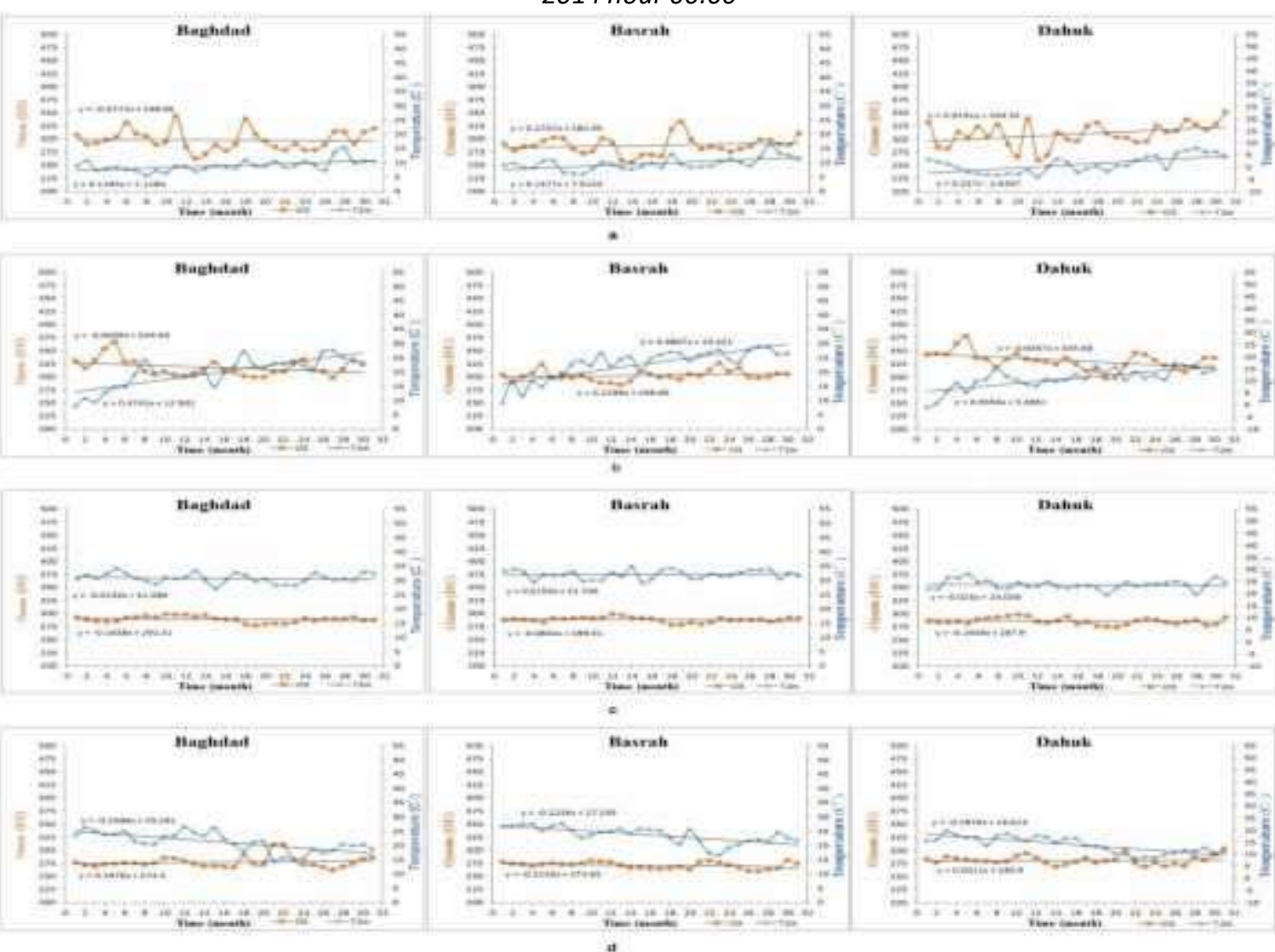

2014 hour 00:00

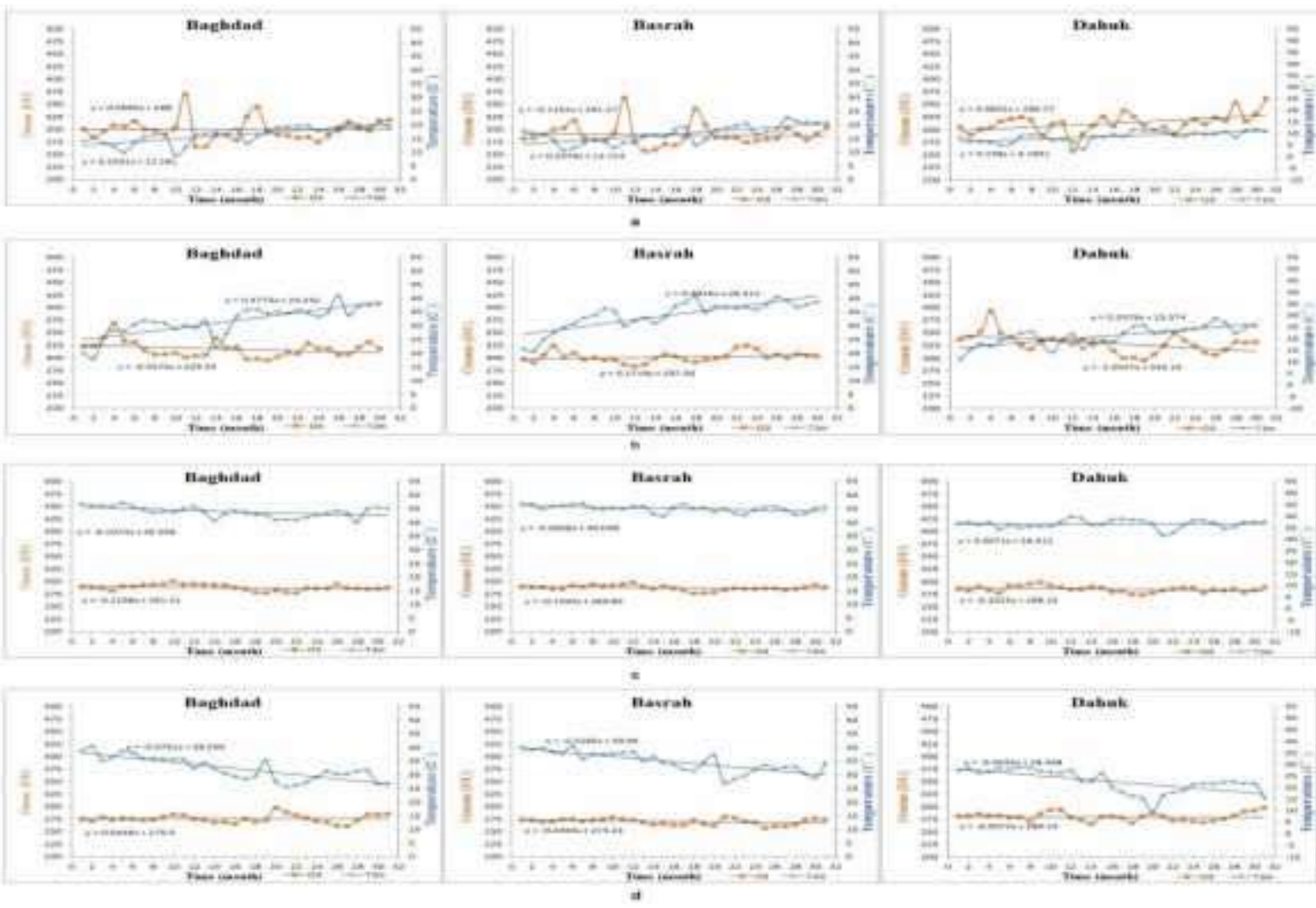

Figure 9: represents the daily average TCO3 and T2m above Iraq

a) January, b) April, c) July, d) October for hour 00 and 12 (year 2014) 
International Journal of Science and Research (IJSR)

ISSN (Online): 2319-7064

Index Copernicus Value (2016): 79.57 | Impact Factor (2015): 6.391

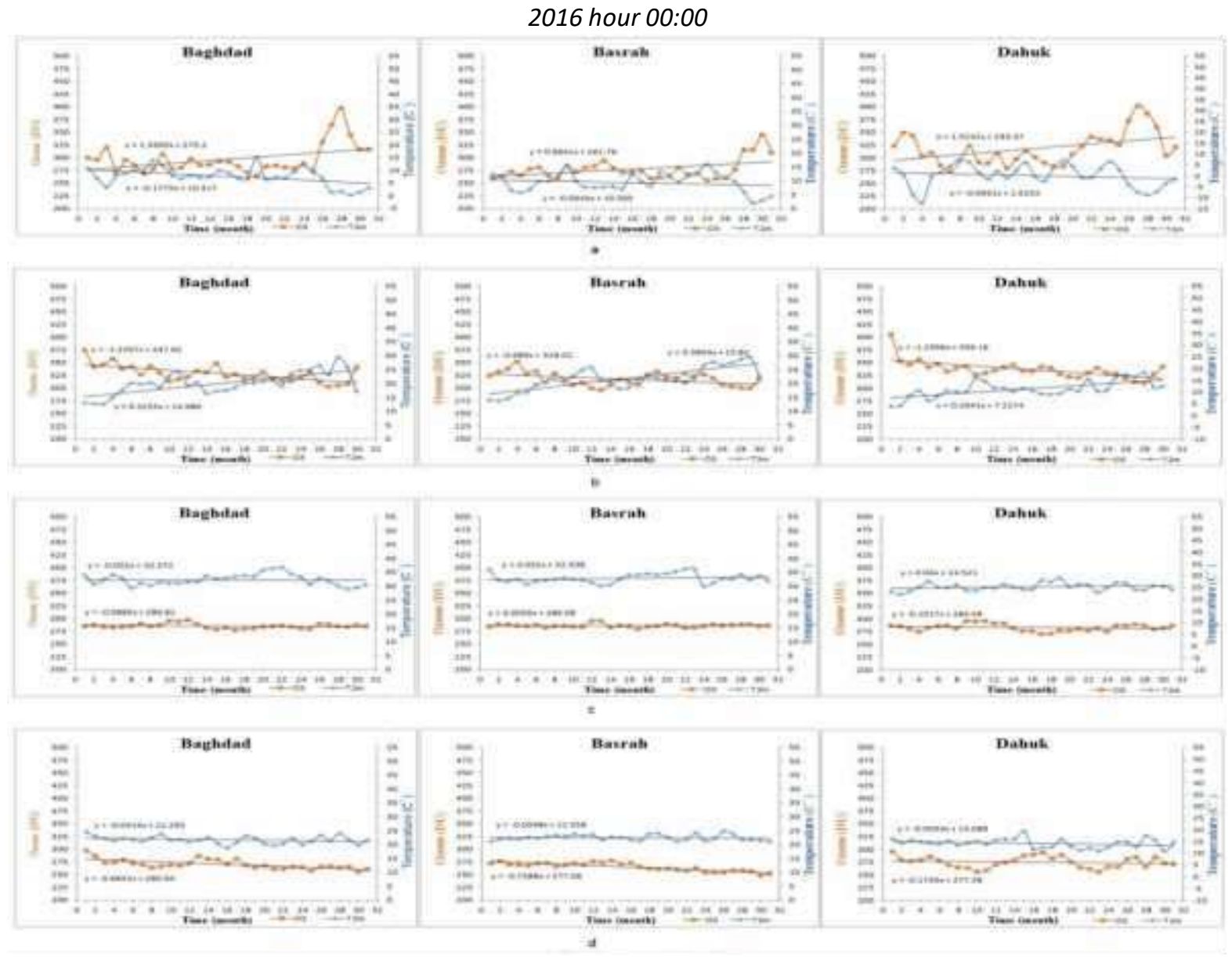

2002 hour 00:00

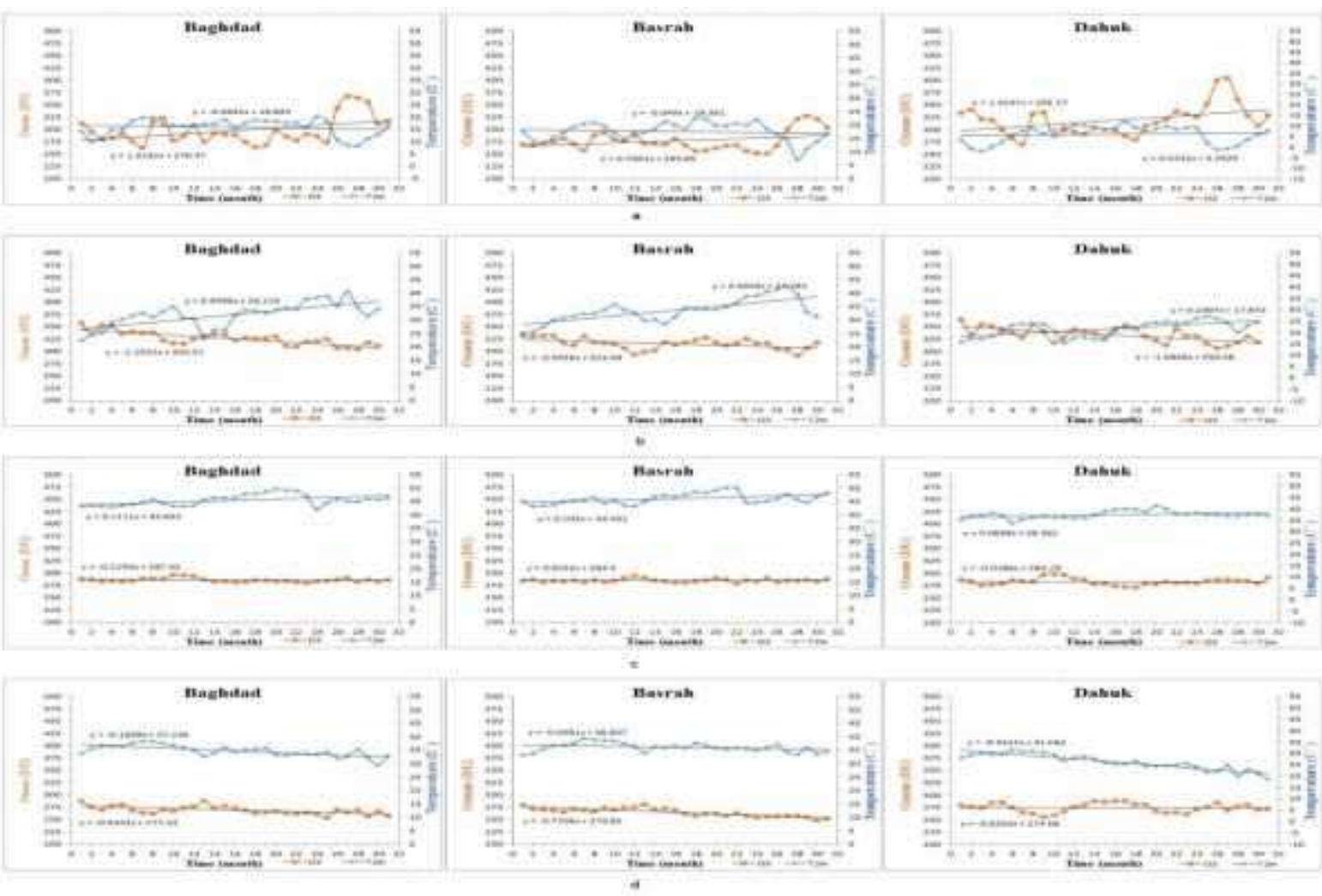

Figure 10: represents the daily average $\mathrm{TCO} 3$ and $\mathrm{T} 2 \mathrm{~m}$ above Iraq a) January, b) April, c) July, d) October for hour 00 and 12 (year 2016)

Volume 6 Issue 12, December 2017

www.ijsr.net

Licensed Under Creative Commons Attribution CC BY 
International Journal of Science and Research (IJSR)

ISSN (Online): 2319-7064

Index Copernicus Value (2016): 79.57 | Impact Factor (2015): 6.391
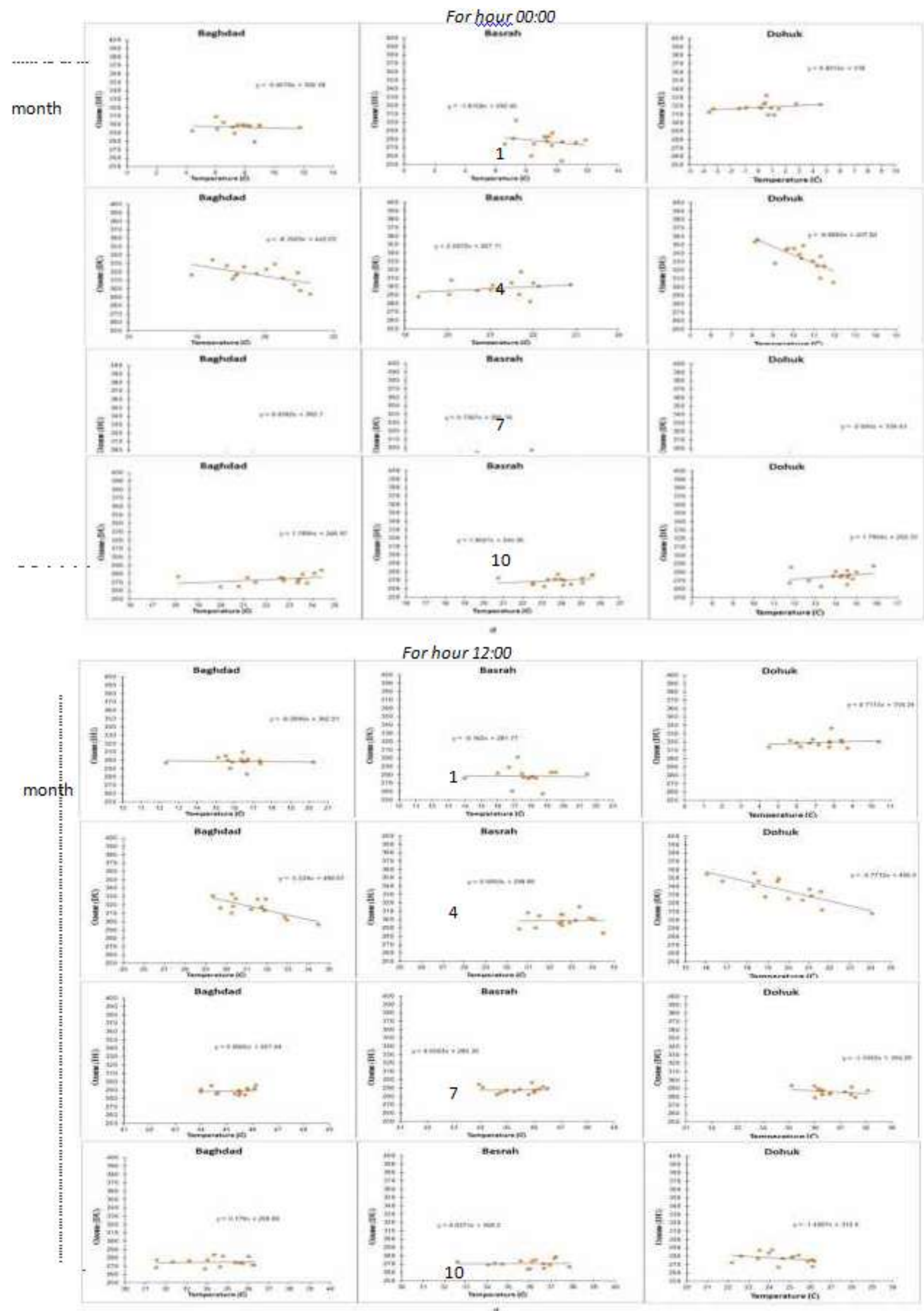

Figure 11: Seasonal variations of TCO3 with T2m for years (2002-2016) at two hours 00:00 and 12:00

Volume 6 Issue 12, December 2017

www.ijsr.net

Licensed Under Creative Commons Attribution CC BY 


\section{International Journal of Science and Research (IJSR)

\section{Acknowledgement}

This work relates to Baghdad University/ College of Science/ Department of Astronomy and Space. The data are provided from the European Centre for Medium-Range Weather Forecasts (ECMWF), for whom I would like to introduce my utmost appreciation and thanks.

\section{References}

[1] Basher, R. E., Review of The Dobson Spectrophotometer and Its Accuracy, Global Ozone Research and Monitoring Projects, Report 13 (World Meteorological Organization, WMO, Geneva.), 1982.

[2] Bass, A. M., and R. J. Paur., The Ultraviolet Cross-sections of Ozone. i. TheMeasurements. ii Results and Temperature Dependence, Atmospheric Ozone; Proceedings of The Quadrennial, pp. 606-616, 1985.

[3] WMO (WORLD METEOROLOGICAL ORGANIZATION). 2007, Scientific Assessment of Ozone Depletion: 2006, Global Research and Monitoring project-Report., No. 50, Geneva.

[4] Intergovernmental Panel on Climate Change (IPCC), Climate Change 2001: Contribution of Working Group I to The Third Assessment Report, Edited by J.T. Houghton et al., 881 pp., Cambridge University Press, New York, 2001.

[5] World Meteorological Organization (WMO)., Scientific Assessment of Ozone Depletion: 2002., WMO Global Ozone Research and Monitoring Project - Report No. 47, 498,pp,Geneva, 2003.

[6] James, P. M., A Climatology of Ozone Miniholes Over the Northern Hemisphere, Int. J. Of Climatol., 18, 1287-1303, 1998.

[7] Newman, P.A., L.R. Lait, and M.R. Schoeberl., The Morphology and Meteorology of SouthernHemisphere Spring Total Ozone Mini-holes., Geophys. Res. Lett., 15, 923- 926, 1988.

[8] Weber, M., K.-U. Eichmann, F. Wittrock, K. Bramstedt, L. Hild, A. Richter, J.P. Burrows, and R. Müller., The Cold Arctic Winter 1995/96 as Observed by GOME and HALOE: Tropospheric Wave Activity and Chemical Ozone Loss., Quart. J. Roy. Meteorol. Soc., 128, 1293-1319, 2002.

[9] Reid, S. J., A. F. Tuck and G. Kildaris., On The Changing Abundance of Ozone Minima at Northern Midlatitudes., J. Geophys. Res., 105(D10), 1216912180, 2000.

[10]Harrison R. M. and Holman C. D., 1982: Ozone pollution in Britain, Chemistry in Britain.

[11]Randel W. J. and Cobb J. B., 1994: Coherent variations of monthly mean total ozone and lower stratospheric temperature, Journal of Geophysical Research, Vol. 99, 5433-5447.

[12] Atkinson R. J., 1997: Ozone variability over the southern hemisphere, Australian Meteorological Magazine, Vol. 46.

[13] Kalf. K, 2006, the Study of Change the total Ozone above some of the cities of the Kingdom of Saudi Arabia during 2004, Journal of Meteorological and the Environment and arid land agriculture.
[14] Steinbrecht W, Bassler B, Claude H, Winkler P, and Stolarski R, 2003: Global distribution of total ozone and lower stratospheric temperature variations, Atmospheric chemistry and physics, 3, 1421-1438.

[15] Hood L. L. and Soukharev B. E, 2005: Interannual variations of total ozone at northern midlatitudes correlated with stratospheric EP flux and potential vorticity, Journal of the atmospheric sciences, vol. 62, 3724-3733.

[16]Zou H, Zhou L, Gao Y, Chen X, Li P. and Ji C, 2005: Total ozone variation between $50^{\circ}$ and $60^{\circ} \mathrm{N}$, Geophysics research letters, vol. 32, L23812- L23816.

[17] Lal. M, 2007: Study of ozone variability at equatorial latitude during severe geomagnetic storm, Bull. Astr. Soc. India, 35, 569-574

[18] Gao Z. Gao W. and Chang N., 2010: Detetion of multidecadal changes in UVB and total ozone concentrations over the continental US with NASA TOMS data and USDA ground-based measurements, Remote Sensing, 2, 262-277, doi: 10.3390/rs2010262.

[19] Antón M, Bortoli D, Costa M, Kulkarni, P, Domingues A, Barriopedro D, Serrano, A and Silva A, 2011: Temporal and spatial variability of total ozone over Portugal, Remote sensing of Environment, vol. $115,855-863$.

[20] Al-Salihi A. M, 2008: Effect of some Atmospheric Factors on Ultraviolet Radiation.p.h.D thesis: AlMustansiriyah University. Atmospheric sciences. Baghdad. Iraq.

[21] Al-Salihi A. M., 2011. Spectral analysis of total ozone column variability using TOMS data over Baghdad, Iraq, International Journal of Energy and Environment, 231-236.

[22] Qassim Z. A, 2013: Study of variations of Total Ozone Columnover Selected Regions at Northern Hemisphere. M.S.C, thesis: Al-Mustansiriyah University. Atmospheric sciences, Baghdad, Iraq.

[23] Hassan Z. M, 2014: Analysis of Temporal and Spatial Patterns of Ozone Over Iraq. M.S.C, thesis: Al-Mustansiriyah University. Atmospheric sciences, Baghdad, Iraq.

[24] Sarah A. M.,Study The effect of Total Ozone Column Distribution On Ultraviolet Radiation for Selected Locations In Iraq, M.S.C, AL- Mustansiriya University College of Science, 2015.

[25]Bushra. A. J, "Direction and Deviation from the Rate-General of the elements of the Climte of Iraq, Journal of the Faculty of Arts, University of AlMustansiriyah, NO.97, 2010.

[26] Balsam Sh. J, "The General Trends of the Frequency of Air masses affecting the Climate of Iraq", P. H. D, Baghdad University, College of Education for Women, Dept. of Geography, 2015.

[27] Ahmed A. H, "Development of a Model for Predicting of Solar Radiation on Inclined Surface Over Iraq and Surrounding Areas", P. H. D, Al- Mustansiriyah University, College of Science, Atmospheric Sciences, 2017.

[28] Ali S. T, "The Local Relationship Between Climate and Human Characteristics and the Desertification and its Effects in Iraq", P. H. D, Department of Geography University of Kufa The College of Education for Women, 2013. 


\section{International Journal of Science and Research (IJSR) \\ ISSN (Online): 2319-7064}

Index Copernicus Value (2016): 79.57 | Impact Factor (2015): 6.391

[29] Ali. H, "The climate Changes", House of Thought for Printing, Publishing and Distribution", first edition, Damascus, 1986.

[30] Abd Al-Haq," Analysis Geographical the Parameters of Climate and Some Phenomena Air in the Province Salahuddin, M. S. C, College of Education, University, of Salahuddin, 2004.

[31] Fisher W, "Physical and social geography in the Middle East and North Africa", Europe publications limited, 1994.

[32] Yavuz, Ercan, "Turkey, Iraq, Syria to initiate water talks", Todays Zaman 12/03/2008.

[33] Azooz A. A, Talal S. K, "Evidence of Climate Change in Iraq" Journal of Environment Protection and Sustainable Development, Vol. 1, No. 2, 2015, pp. 66-73, 2015.

Volume 6 Issue 12, December 2017

www.ijsr.net

Licensed Under Creative Commons Attribution CC BY 